\title{
Continuous-flow processes for the catalytic partial hydrogenation reaction of alkynes
}

\author{
Carmen Moreno-Marrodan, Francesca Liguori and Pierluigi Barbaro*
}

\author{
Review \\ Address: \\ Consiglio Nazionale delle Ricerche, Istituto di Chimica dei Composti \\ Organo Metallici, Via Madonna del Piano 10, 50019 Sesto Fiorentino, \\ Firenze, Italy \\ Email: \\ Pierluigi Barbaro* - pierluigi.barbaro@iccom.cnr.it \\ * Corresponding author \\ Keywords: \\ alkynes; heterogeneous catalysis: hydrogenation; flow; liquid-phase
}

Beilstein J. Org. Chem. 2017, 13, 734-754.

doi:10.3762/bjoc. 13.73

Received: 15 December 2016

Accepted: 29 March 2017

Published: 20 April 2017

This article is part of the Thematic Series "Automated chemical synthesis".

Guest Editor: I. R. Baxendale

(C) 2017 Moreno-Marrodan et al.; licensee Beilstein-Institut.

License and terms: see end of document.

\begin{abstract}
The catalytic partial hydrogenation of substituted alkynes to alkenes is a process of high importance in the manufacture of several market chemicals. The present paper shortly reviews the heterogeneous catalytic systems engineered for this reaction under continuous flow and in the liquid phase. The main contributions appeared in the literature from 1997 up to August 2016 are discussed in terms of reactor design. A comparison with batch and industrial processes is provided whenever possible.
\end{abstract}

\section{Introduction}

The catalytic partial hydrogenation of alkynes to alkenes in the liquid phase is a reaction of high relevance to the manufacture of a multitude of fine chemicals [1] including pharmaceutical building blocks, agrochemicals, food additives, flavours and fragrances [2,3]. It is also crucial in the bulk polymer industry to achieve the complete elimination of alkynes and alkadienes from alkene feedstocks $[4,5]$. The chemistry of these processes is dominated by heterogeneous palladium catalysts, particularly based on solid-supported Pd nanoparticles (PdNP) [6,7]. On the industrial scale, alkynes partial hydrogenations are usually carried out under batch conditions using Lindlar-type catalysts, consisting in relatively high amounts of $\mathrm{Pd}(5 \mathrm{wt} \%)$ and $\mathrm{Pb}$ (2-3\%) deposited onto $\mathrm{CaCO}_{3}[8,9]$, whose active sites nature is not fully characterized yet $[10,11]$. Besides the use of toxic lead, satisfactory catalyst performances often require a careful control of the hydrogen uptake and use of an excess of amine (quinoline) modifier $[12,13]$, with serious drawbacks in terms of process economy, environmental impact and product separation management. The development of cost-effective, well-defined, efficient and environmentally friendly catalytic systems for the partial hydrogenation reaction of alkynes is thus of utmost importance $[14,15]$. 
Compared to batch setups, considerable process intensification $[16,17]$ to this regard can be provided by continuous-flow operations either in terms of safety, purification, waste emission, durability, reproducibility, automation, energy and space consumption [18,19]. Particularly, continuous-flow catalysis may enhance the performance of a given catalyst while reducing the number of processing steps [20,21], which may result in a significant contribution to the reduction of the high E-factor ( $\mathrm{kg}$ waste generated/ $\mathrm{kg}$ product) usually observed in the fine-chemicals sector [22,23], as a consequence of the additives and manipulations required to achieve satisfactory selectivity. Indeed, the implementation of continuous-flow practices in the pharmaceutical industry is considered one of the most strategic fields of innovation toward greener manufacturing methods [24,25]. Nonetheless, in order to be competitive on the large-scale, continuous-flow systems for the catalytic hydrogenation of alkynes should not only provide their intrinsic benefits over conventional batch processes, but also be advantageous, or at least equal, either in terms of productivity per unit active metal, volume or time, absence of additives or catalyst lifetime [26,27].

In the present paper we shortly review the heterogeneous catalytic systems engineered for the partial hydrogenation reaction of substituted and unsubstituted alkynes under continuous flow and in the liquid phase, covering the main contributions appeared in the literature from 1997 up to August 2016. Some aspects of the topic have been surveyed in the past $[28,29]$. Details of alkyne hydrogenation reactions in general, including mechanism [30,31], kinetics [32,33], adsorption phenomena $[34,35]$, thermodynamics [36,37], structure-activity relationships $[38,39]$ have been extensively described elsewhere, therefore they are out of the scope of this review. Herein the focus is on the various catalytic reactor systems and technological solutions reported in the literature for this process, aimed at illustrating the state of the art in the field and the benefits of the approach. Generalities on theory and methods for flow chemistry can be found in excellent textbooks and reviews [40,41] and will not be treated in detail.

The present review could have been structured according to different variables, i.e., the metal catalyst involved, the type of support material, the reactor design or the hydrogen source. We decided to break down the manuscript on the basis of the substrates examined in order to allow an easier comparison among different reactors performance and highlight the potential benefits of one catalytic system over the others.

\section{Review}

\section{The issue of selectivity}

A major challenge in alkynes partial hydrogenation is to achieve $100 \%$ selectivity to the desired product at the highest conversion level $[42,43]$. The conventional heterogeneous catalysts often show selectivity issues owing to many potential side reactions, particularly in relation to chemoselectivity, i.e., overhydrogenation of alkenes to alkanes $[44,45]$, resistance of other functional groups (ketones [46,47], amines [48,49], azides [50]), regioselectivity [51,52], isomerization [53,54] and oligomerization $[55,56]$ competitive reactions. In addition, whenever an internal alkyne is to be hydrogenated, stereoselectivity must also be considered [57] (Scheme 1). The main byproduct usually obtained is the over-hydrogenation one, which results in conversion and selectivity to be inversely proportional. Selectivity in partial hydrogenation is ruled by the relative rates of the first and second hydrogenation steps, as well as by the adsorption strengths of alkyne and alkene over the metal catalyst surface. Other side-products may include those due to dimerization and isomerization reactions, depending on the substrate.

Several approaches were developed to enhance the selectivity of the batch hydrogenation processes, including tuning of the reaction conditions, use of less conventional metals [58,59], alloys $[60,61]$ or oxide active phases [62] and engineering of singlesite heterogeneous catalysts $[63,64]$. A more usual strategy is the so-called "selective poisoning", i.e., the improvement of the catalyst's selectivity by the addition of variable, often large, amount of contaminants, either organic ligands (quinolone [65,66], phosphine [67]), carbon monoxide [68], sulfides [69], sulfoxides [70,71] defined as "reaction modifiers", or metal ions $(\mathrm{Cu}, \mathrm{Pb})$ [72], polymers/surfactants [73] defined "catalyst modifiers", whose common purpose is to decrease the hyperactivity of the (Pd) metal. It is clear that, besides the use and consumption of toxic/expensive substances, drawbacks in terms of cata-

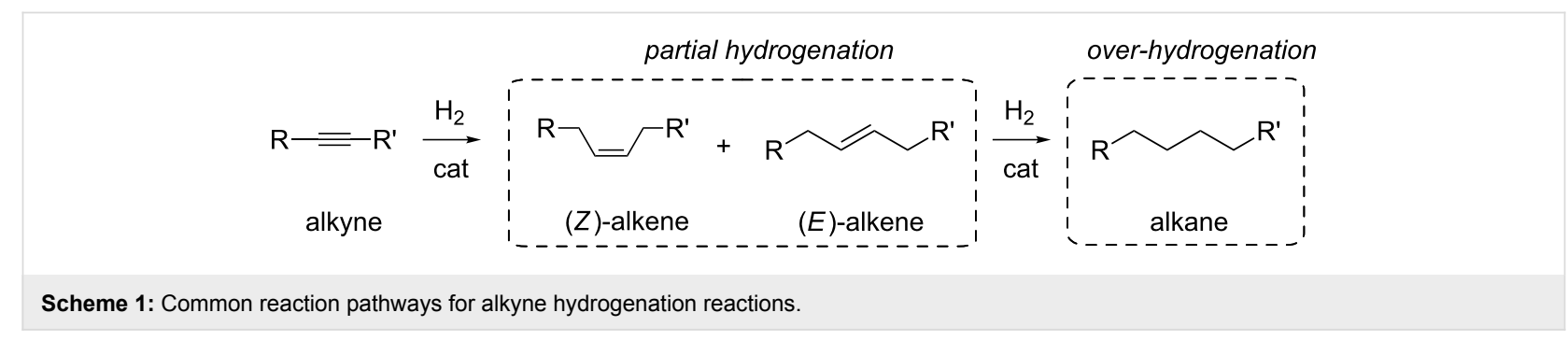


lyst reuse and deactivation pose severe limitations in the utilization of this approach.

As it will be illustrated in the following sections, hydrogenation under continuous-flow conditions may represent a favourable alternative. Catalytic flow systems have shown to be extremely beneficial for carrying out chemical processes that are difficult to perform under batch conditions, e.g., involving reactive intermediates or competitive reactions [74,75]. Compared to batch setups, performing reactions under continuous flow allows a fine tuning of the contact time between intermediates and catalytic active phase, which may result in improved selectivity, with no need of additives [76].

\section{Reactor and catalyst design}

In contrast to unselective processes in the gas phase (e.g., for bulk chemicals production), whose fast interaction with the catalyst may ensure satisfactory conversions under the reaction conditions, selective liquid phase flow processes for the finechemicals synthesis, including partial hydrogenations, usually requires a more intimate contact with the heterogeneous catalyst to be efficient. One example is the so-called "confinement effect" found in mesoporous catalytic materials [77,78].

Catalytic hydrogenations are conveniently achieved under flow using fixed bed devices, wherein the size of the inner diameter of reactor channels distinguishes between micro $(10-500 \mu \mathrm{m})$ or mesofluidic $(500 \mu \mathrm{m}$ up to several $\mathrm{mm})$ reactors $[79,80]$. This size range may allow for the production of $\mathrm{mg}$ to tens of tons of target compound per year [81]. Despite the several possible reactor arrangements and catalyst morphologies falling within the above classification $[82,83]$, herein we decided to break down the systems according to the main types reported in the literature for the catalytic partial hydrogenation reaction of alkynes, i.e., capillary, packed-bed, honeycomb and monolithic reactors. A schematic representation of these reactors is shown in Figure 1. Other reactor types (e.g., fluidized bed reactor, wherein the solid catalyst is suspended in a fluid) have not been reported for liquid-phase alkyne hydrogenations and will not be discussed.

Capillary reactors $(10-1000 \mu \mathrm{m}$ internal diameter, $0.1-30 \mathrm{~m}$ length) are routinely used in the lab-scale synthesis due to the ease of operations, negligible heat effects and fast reactants mixing $[84,85]$. Issues may arise from miniaturization of the catalysts, where the most common approach is to immobilize the catalyst onto the inner wall of the capillary support (catalytic wall reactors) $[86,87]$ or to pack the powdered catalyst into the microchannels [88], the latter strategy being prone to significant pressure drops due to either the swelling or the size of the catalyst. It is important mentioning that different flow regimes

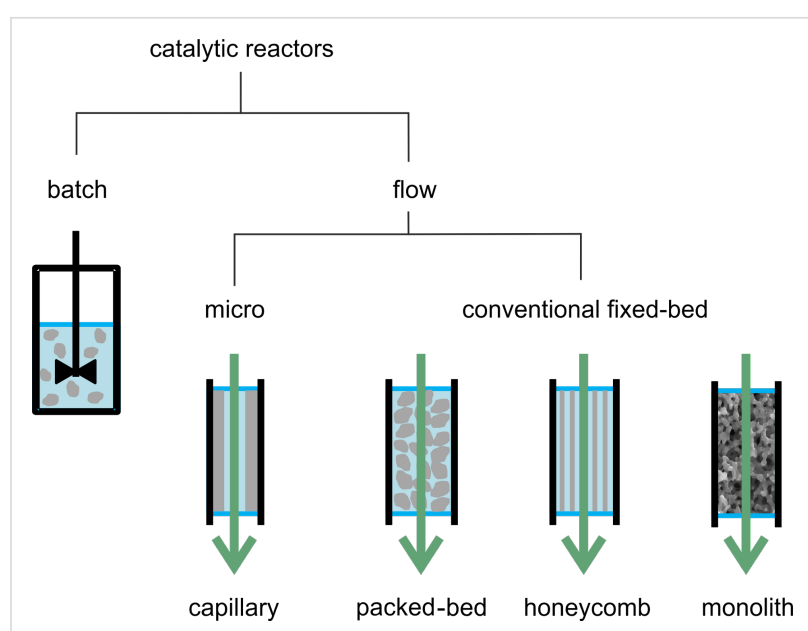

Figure 1: Schematic representation of most common reactor types for batch and continuous-flow partial hydrogenation of alkynes. Particles, layer or body of the catalyst in grey.

can be attained in miniaturized channels, depending on the gas and liquid rates, as these may affect both conversion and selectivity of the process (Figure 2).

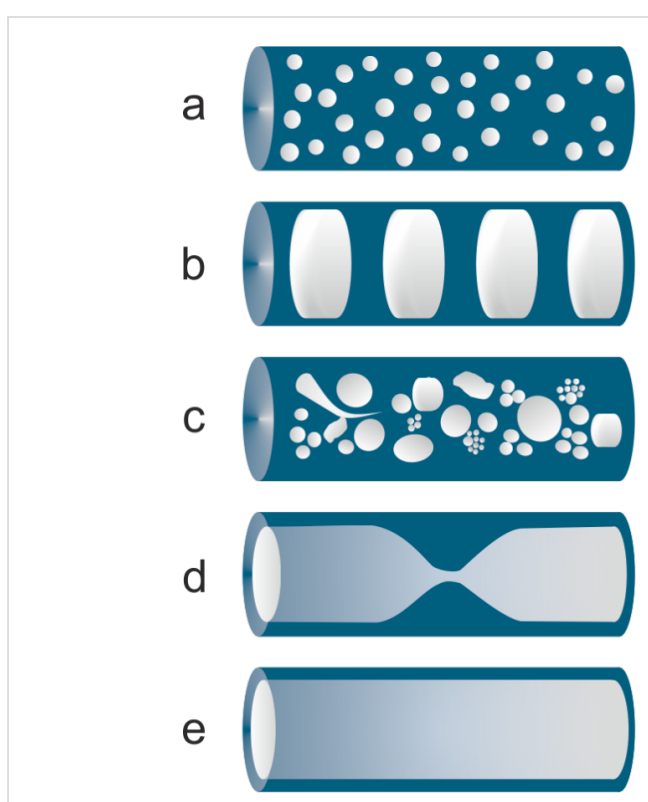

Figure 2: Schematic representation of flow regimes in microchannels; (a) bubbly flow, (b) slug/Taylor or segmented flow, (c) churn flow, (d) slug/annular flow, (e) annular flow.

Packed-bed reactors are among the most used systems since they are relatively simple to handle, easy to operate and can accommodate beds with a broad range of physical dimensions and shapes. Commonly used packed catalysts consist of metal nanoparticles (MNP) immobilized onto a variety of porous solid supports, either pellets or powders of various grain size (in the range $\mu \mathrm{m}$ to $\mathrm{mm}$ ). The preferred choice are mesoporous 
supports (2-50 nm cavity size), due to the enhanced contact with the reagents because of the high surface area $[89,90]$ and the effective "steric" stabilization of the embedded metal nanoparticle catalysts [91,92]. However, mesoporous catalysts may suffer from pore clogging, active sites accessibility, mass transfer limitations, and lack of reproducibility. Additional stabilization of MNP can be also achieved either by: the "electrostatic" effect of charged functional groups grafted to the support, a common strategy in gel-type resins (e.g., sulfonic resins) [93]; the strong metal-support interactions, particularly for inorganic oxide materials, e.g., $\mathrm{TiO}_{2}$ [94,95]. Besides contributing to catalyst resistance by hampering the loss and the size increase of active sites, MNP stabilization is a key factor to limit the amount of metal leached in solution, an issue of utmost importance for the reduction of metal residues in the food and pharmaceuticals manufacture industry [96]. The choice of appropriate support materials is therefore critical to this purpose. Alternative strategies to reduce metal contamination include the use of metal scavengers, usually in the form of a downstream located cartridge [97].

Honeycomb (or foam) catalysts consist of inert carrier materials with millimetre size parallel channels (or cavities) obtained by extrusion, onto which a catalytically active layer is deposited, usually a porous inorganic oxide bonded to the support surface and containing precious metal sites (washcoat) $[98,99]$. They are largely reported in the chemical engineering literature for gas-phase, unselective thermal processes $[100,101]$.

A monolith is "a shaped, fabricated intractable article with a homogeneous microstructure that does not exhibit any structural components distinguishable by optical microscopy" [102]. According to this definition, honeycombs do not fall within this category. In the recent years, porous monoliths have attracted considerable interest in several flow-through applications for the fine chemistry, including chromatography and catalysis $[103,104]$. Monolithic reactors may surpass most drawbacks typical of packed-bed systems, including high pressure drops, low contacting efficiency, large distribution of residence times, formation of hot-spots or stagnation zones, which results in poorly controlled fluid dynamics, hence in low catalyst productivity and selectivity $[105,106]$. Particularly, monoliths featuring a 3D isotropic, hierarchically porous network of narrowly size distributed, interconnected macropores $(1-30 \mu \mathrm{m})$ and mesopores within the struts $(6-50 \mathrm{~nm})$ have shown a unique hydrodynamic behavior in the liquid phase [107,108], which addresses the need of both efficient processing (within small pores) and effective mass transport (by macropores) [109,110]. This kind of monolith obtained by spinodal decomposition joins the advantages of high surface area typical of mesoporous mate- rial, spanning from 200 to $1200 \mathrm{~m}^{2} \mathrm{~g}^{-1}$ [111] with a high permeability typical of macropores, which results in a very efficient mass transfer [112]. According to Darcy's law, describing the flow of a fluid through a porous medium, hierarchically porous monoliths show a very low pressure drop $\Delta p$ per unit reactor length $L(\Delta p / L=(\mu v) / k$, $\mu$ viscosity; $v$ linear velocity), thanks to the high permeability coefficient $k>0.25 \mu \mathrm{m}^{2}$, which is proportional to the macroporous size $D^{2}$ [113]. The catalytic performance of these monoliths has been compared in continuous flow as a single piece or packed-bed (ground monolith $60-120 \mu \mathrm{m}$ ) and in batch arrangements. The better productivity was clearly demonstrated for the entire monolith under flow in the hydrogenation reaction of cyclohexene, resulting in turnover frequencies of 1673,1131 and $932 \mathrm{~h}^{-1}$ and space-time-yields of $4.02,0.95$ and $0.01 \mathrm{~kg}_{\text {product }} \mathrm{L}_{\text {reactor }}{ }^{-1} \mathrm{~h}^{-1}$, respectively [109]. An analogous permeability was observed under flow for 1D nanostructured support materials (vide infra).

A typical equipment for liquid-phase continuous-flow hydrogenations is sketched in Figure 3. Usually, concurrent, controlled flows of substrate solution and $\mathrm{H}_{2}$ gas are allowed to flow through the catalytic reactor. Reaction products are collected at the reactor outlet. Typical residence times for alkynes partial hydrogenations, which defines the amount of time that the reaction mixture spends inside the reactor (the volume of the reactor divided by the volumetric flow rate) [114], are in the range $10-1000 \mathrm{~s}$, corresponding to $5 \mu \mathrm{L} / \mathrm{min}$ (for capillary reactors) up to $3 \mathrm{~mL} / \mathrm{min}$ of substrate solution flow. Hydrogen flow rates (and pressures) are adjusted to have typical $\mathrm{H}_{2}$ : substrate molar ratios inside the reactor in the range of $1-30$.

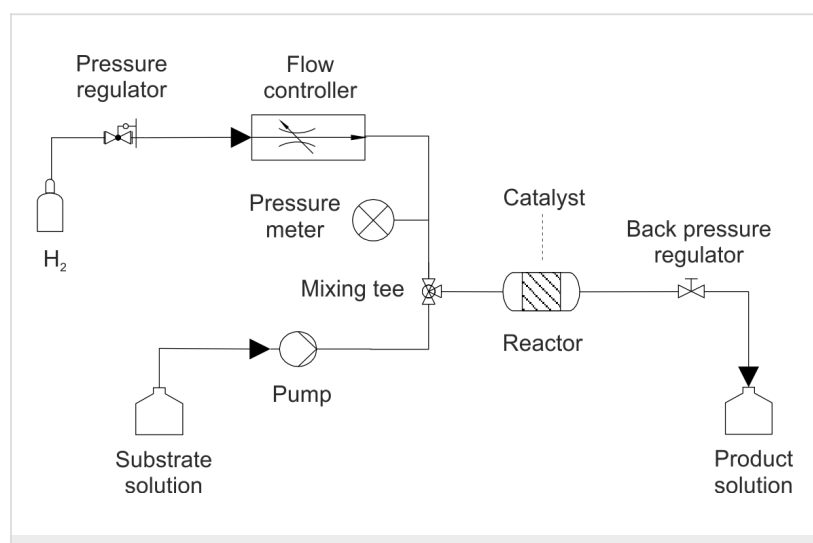

Figure 3: Sketch of typical continuous flow apparatus for liquid-phase catalytic alkynes hydrogenation reactions.

\section{Hydrogenation of terminal alkynes}

Various terminal alkynes have been hydrogenated under continuous-flow conditions using supported catalysts. The substrates and the commonly observed products with the labelling adopted in the present review are shown in Scheme 2. Representative 
<smiles>C#CCCCCCC</smiles>

2

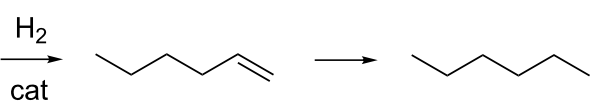

$1 a$

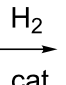

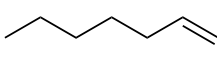

$2 a$ 1b<smiles>CCCCCCC</smiles>

2b<smiles>C#CC(=C)O</smiles><smiles>C=C[C@](C)(O)CC</smiles>

$3 a$<smiles>CCC(C)C(C)CC</smiles>

3b

3c<smiles>C#CC(C)(O)CC</smiles>

4

$$
\underset{\text { cat }}{\stackrel{\mathrm{H}_{2}}{\longrightarrow}}
$$<smiles>C=CC(C)(O)CC</smiles>

$4 a$<smiles>CCC(C)CC(C)CC</smiles>

4b 4c<smiles>C#CC(C)C(O)C1CCCCC1</smiles>

5<smiles>C#CC(O)(c1ccccc1)P(=C)(F)c1ccccc1</smiles>

6

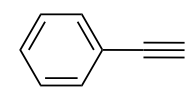

7

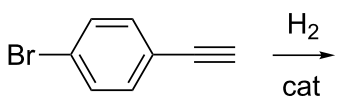

8

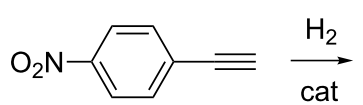

9<smiles>C=CC(C)[C@H](O)C1CCCCC1</smiles>

$5 a$<smiles>CCC(C)[C@H](O)C1CCCCC1</smiles>

$5 b$<smiles>CCC(c1ccccc1)C(O)(CC)[Pb]([18O])([18O])c1ccccc1</smiles><smiles>C=Cc1ccc(CC)cc1</smiles>
$7 \mathrm{~b}$<smiles>C=Cc1ccc(Br)cc1</smiles>

$8 a$<smiles>C=Cc1ccc([N+](=O)[O-])cc1</smiles>

9a

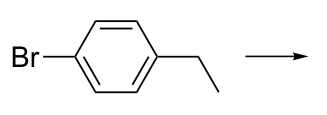

$8 b$

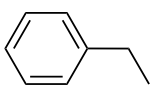

$8 \mathrm{c}$

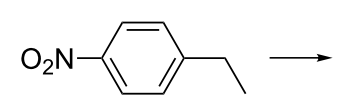

$9 b$

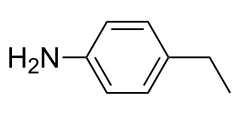

9c

Scheme 2: Hydrogenation reactions of terminal alkynes with potential products and labelling scheme.

data are summarized in Table 1, in which conversions are indicated and catalysts' efficiencies are expressed in terms of selectivity, yield of indicated product, mass productivity $\left(\right.$ mol $_{\text {product }}$ gmetal $^{-1} \mathrm{~h}^{-1}$ ) and space-time-yield (STY) [115]. Whenever available, the best compromise results between conversion and selectivity are reported.

\section{1-Hexyne and 1-heptyne}

The partial hydrogenation of 1-hexyne (1) produces 1-hexene (1a), one of the most commercially important linear $\alpha$-olefins used in copolymerization processes [116,117]. High density polyethylene (HDPE) and linear low density polyethylene (LLDPE) contain approximately $2-4 \%$ and $8-10 \%$ of $1 \mathrm{a}$, re- spectively [118]. 1-Hexene can be produced in ca. 91\% yield under batch conditions using bimetallic Pd (4 wt \%)-Cu ( $2 \mathrm{wt} \%$ ) catalysts immobilized onto silica $\left(298 \mathrm{~K}, 1\right.$ bar $\left.\mathrm{H}_{2}\right)$ [65].

1-Hexyne was used as benchmark substrate to compare the efficiency of various packed-bed hydrogenation catalysts under continuous flow. Outstanding 1a yields were obtained either using the Lindlar catalyst (84.6\%) under smooth reaction conditions $\left(298 \mathrm{~K}, 1\right.$ bar $\mathrm{H}_{2}$, Table 1 , entry 1) or 16.2 wt \% $\mathrm{CeO}_{2} @ \mathrm{TiO}_{2}(97 \%)$, the latter resulting in a very high STY for $1 \mathrm{a}\left(18.86 \mathrm{~kg} \mathrm{~L}^{-1} \mathrm{~h}^{-1}\right)$ under solvent-free conditions (Table 1, entry 2) [119]. Use of cerium oxide is certainly advantageous in 


\begin{tabular}{|c|c|c|c|c|c|c|c|c|c|c|}
\hline entry & alkyne & reactor $^{a}$ & catalyst & $\begin{array}{c}T \\
(\mathrm{~K})\end{array}$ & $\begin{array}{c}\text { conv. }^{b} \\
(\%)\end{array}$ & $\begin{array}{c}\text { selectivity } \\
(\%)\end{array}$ & $\begin{array}{c}\text { yield }^{d} \\
(\%)\end{array}$ & $\begin{array}{c}\operatorname{prod.}_{-, e},-1 \\
\left(\operatorname{mol~g}_{M}^{-1} h^{-1}\right)\end{array}$ & $\begin{array}{c}\mathrm{STY} \\
\left(\mathrm{kg} \mathrm{L}^{-1} \mathrm{~h}^{-1}\right)\end{array}$ & ref. \\
\hline 1 & 1 & PB & $5 \% \mathrm{Pd}(\mathrm{Pb}) @ \mathrm{CaCO}_{3}$ & 293 & $90^{f}$ & 94 & 84.6 & 2.9 & 1.65 & [119] \\
\hline 2 & 1 & PB & 16.2\% $\mathrm{CeO}_{2} @ \mathrm{TiO}_{2}$ & 413 & $97^{g, h}$ & 100 & 97.0 & 1.1 & 18.86 & [119] \\
\hline 3 & 1 & PB & 0.6\% Pd(HHDMA)@C & 293 & $30^{f}$ & 97 & 29.1 & 0.8 & 0.13 & [121] \\
\hline 4 & 1 & PB & 0.5\% Pd(HHDMA)@TiS & 293 & $30^{f}$ & 96 & 28.8 & 0.9 & 0.13 & [121] \\
\hline 5 & 1 & PB & $1.0 \% \mathrm{Pd} @ \mathrm{Al}_{2} \mathrm{O}_{3}$ & 293 & $30^{f}$ & 67 & 20.1 & 0.3 & 0.09 & [121] \\
\hline 6 & 1 & PB & 0.5\% Pd@mpg-C3N4 & 343 & $--^{i, j}$ & 90 & $-\mathrm{i}$ & 13.3 & $-\mathrm{i}$ & [122] \\
\hline 7 & 1 & PB & 1.3\% Ag@SiO 2 & 373 & $30^{\mathrm{k}}$ & 95 & 28.5 & 0.1 & 0.13 & [123] \\
\hline 8 & 1 & PB & 1\%Au@TiO 2 & 373 & $40^{k}$ & 95 & 38.0 & 0.1 & 0.17 & [123] \\
\hline 9 & 1 & PB & 1\% Ag@TCM-mpg-C3N4 & 303 & $-{ }^{\mathrm{i}, \mathrm{k}}$ & 100 & $-{ }^{i}$ & 0.9 & 0.56 & [124] \\
\hline 10 & 3 & C & $1 \% \mathrm{Pd}_{25} \mathrm{Zn}_{75} @ \mathrm{TiO}_{2}$ & 333 & $>99^{1}$ & 90 & 89.4 & 5.3 & $<0.01$ & [131] \\
\hline 11 & 3 & M & 0.67\% Pd@MonoBor & 294 & $92^{1}$ & 94 & 86.4 & 16.2 & 1.52 & [136] \\
\hline 12 & 3 & PB & 0.5\% Pd@TiNT & 294 & $75^{1}$ & 83 & 62.2 & 82.3 & 7.36 & [137] \\
\hline 13 & 3 & PB & 0.6\% Pd(HHDMA)@C & 293 & $30^{f}$ & 100 & 30.0 & 0.9 & 0.17 & [121] \\
\hline 14 & 3 & PB & 0.5\% Pd(HHDMA)@TiS & 293 & $30^{f}$ & 96 & 28.8 & 1.0 & 0.16 & [121] \\
\hline 15 & 3 & PB & $5 \% \mathrm{Pd}(\mathrm{Pb}) @ \mathrm{CaCO}_{3}$ & 293 & $30^{f}$ & 83 & 24.9 & 0.1 & 0.14 & [123] \\
\hline 16 & 3 & PB & 1.3\% Ag@SiO 2 & 373 & $30^{k}$ & 100 & 30.0 & 0.1 & 0.17 & [123] \\
\hline 17 & 3 & PB & 1\%Au@TiO 2 & 373 & $30^{\mathrm{k}}$ & 100 & 30.0 & 0.1 & 0.17 & [123] \\
\hline 18 & 3 & PB & 0.5\% Pd@mpg-C3N4 & 343 & $--^{\mathrm{i}, \mathrm{j}}$ & 90 & $-i$ & 13.2 & $-i$ & [122] \\
\hline 19 & 3 & PB & 0.1\% Pd@NKZPDB-5 & 294 & $>99^{\prime}$ & 60 & 59.4 & 5.8 & 0.17 & [141] \\
\hline 20 & 4 & C & 0.02 wt \% Pd@ $@ \mathrm{Al}_{2} \mathrm{O}_{3}$ & 293 & $94^{f}$ & 83 & 78.0 & $-i$ & $-\mathrm{i}$ & [142] \\
\hline 21 & 5 & PB & $5 \% \mathrm{Pd}(\mathrm{Pb}) @ \mathrm{CaCO}_{3}$ & 298 & $95^{\mathrm{k}}$ & 100 & 95 & $-\mathrm{i}$ & $-\mathrm{i}$ & [143] \\
\hline 22 & 6 & M & 0.67\% Pd@MonoBor & 294 & $85^{1}$ & 84 & 71.3 & 0.9 & 0.20 & [136] \\
\hline 23 & 6 & PB & 0.5\% Pd@TiNT & 294 & $78^{1}$ & 89 & 69.4 & 20.0 & 4.37 & [137] \\
\hline 24 & 6 & PB & 5\%Pd(Pb)@CaCO 3 & 293 & $30^{f}$ & 100 & 30.0 & 0.1 & 0.39 & [123] \\
\hline 25 & 6 & PB & $16 \% \mathrm{CeO}_{2} @ \mathrm{TiO}_{2}$ & 413 & 519 & 100 & 51.0 & $<0.1$ & 0.29 & [119] \\
\hline 26 & 6 & PB & 1.3\% Ag@SiO 2 & 373 & $30^{\mathrm{k}}$ & 96 & 28.8 & 0.1 & 0.38 & [123] \\
\hline 27 & 6 & PB & 1\% Au@ $\mathrm{TiO}_{2}$ & 373 & $30^{k}$ & 100 & 30.0 & 0.1 & 0.39 & [123] \\
\hline 28 & 7 & PB & $16 \% \mathrm{CeO}_{2} @ \mathrm{TiO}_{2}$ & 413 & $100^{9}$ & 100 & 100.0 & $<0.1$ & 0.25 & [119] \\
\hline 29 & 7 & M & 0.67\% Pd@MonoBor & 294 & $98^{1}$ & 96 & 93.7 & 2.9 & 0.33 & [136] \\
\hline 30 & 7 & PB & 0.5\% Pd@TiNT & 294 & $83^{1}$ & 82 & 68.1 & 6.5 & 0.71 & [137] \\
\hline 31 & 7 & PB & $5 \% \mathrm{Pd}(\mathrm{Pb}) @ \mathrm{CaCO}_{3}$ & 293 & $30^{f}$ & 98 & 29.4 & 0.1 & 0.17 & [123] \\
\hline 32 & 7 & PB & 1.3\% Ag@ $\mathrm{SiO}_{2}$ & 373 & $30^{k}$ & 100 & 30.0 & 0.1 & 0.18 & [123] \\
\hline 33 & 7 & PB & 1\%Au@TiO 2 & 373 & $30^{k}$ & 96 & 28.8 & 0.1 & 0.17 & [123] \\
\hline 34 & 7 & PB & 0.3\% Au@ $\mathrm{TiO}_{2}$ & 333 & $99^{m}$ & 100 & 99 & 1.9 & 0.67 & [151] \\
\hline
\end{tabular}

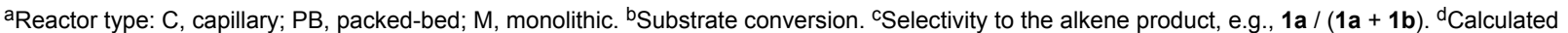
on the basis of the alkene product. ${ }^{e}$ Calculated on bulk supported metal loading. ${ }^{\mathrm{f}_{1}}$ bar $\mathrm{H}_{2} .{ }^{9} 90$ bar $\mathrm{H}_{2}$. ${ }^{\mathrm{h}} \mathrm{Solvent}-\mathrm{free}$. 'Not available. ${ }^{\mathrm{j}} 5$ bar $\mathrm{H}_{2}$. ${ }^{\mathrm{k}} 10 \mathrm{bar}$ $\mathrm{H}_{2} \cdot{ }_{1}-2.7$ bar $\mathrm{H}_{2}$. ${ }^{\mathrm{m}} \mathrm{No} \mathrm{H}_{2}$ pressure specified.

terms of catalyst cost, however, it requires much stronger reaction conditions to afford conversions analogous to that of Pd (413 K, 90 bar $\mathrm{H}_{2}$ ). Comparable selectivities, although at lower conversion level, were reported using ligand-modified Pd catalysts, namely hexadecyl-2-hydroxyethyl-dimethylammonium dihydrogen phosphate (HHDMA), commercially available under the name NanoSelect ${ }^{\mathrm{TM}}$ [120]. Low-content, colloidal
HHDMA-palladium catalysts onto on activated carbon (Table 1, entry 3 ) or titanium silicate (Table 1, entry 4) provided selectivities for 1 a of $97 \%$ and $96 \%$ respectively. As expected, "bare" $1 \% \mathrm{Pd} @ \mathrm{Al}_{2} \mathrm{O}_{3}$ (Table 1, entry 5) showed to be poorly selective $(67 \%)$, resulting in considerable amounts of oligomers and over-hydrogenated product $\mathbf{1 b}$ [121]. The performance of the above systems was compared with that of a single-site catalyst 
based on Pd atoms confined into the "six-fold cavities" of a mesoporous polymeric graphitic carbon nitride (mpg-C3N4, Figure 4a) [122]. The catalyst showed the highest productivity in the series $\left(13.3 \mathrm{~mol}_{1 \mathbf{a}} \mathrm{g}_{\mathrm{Pd}}{ }^{-1} \mathrm{~h}^{-1}\right)$, under fairly mild conditions $\left(343 \mathrm{~K}, 5\right.$ bar $\left.\mathrm{H}_{2}\right)$ (Table 1, entry 6 ), which was attributed to the facile hydrogen activation and alkyne adsorption on the atomically dispersed Pd sites. Electrostatic stabilization of Pd atoms was ascribed to a strong interaction with the nitrogencoordinating species on the basis of DFT calculations. Effective stabilization also prevented site aggregation, resulting in pretty constant catalytic activity over a $20 \mathrm{~h}$ time-on-stream.

As an alternative to poisoned PdNP, use of other noble metals was also explored, although with lower catalysts efficiency. For instance, Ag@SiO 2 (Table 1, entry 7) and Au@ $\mathrm{TiO}_{2}$ (Table 1, entry 8 ) provided 1a with modest yields and productivities under more severe reaction conditions compared to Pd (373 K, $10 \mathrm{bar}_{2}$ ) [123]. Interestingly, the productivity of these systems could be significantly improved by adopting the same atomic level dispersion approach above described for palladium. Thus, Ag onto tricyanomethanide doped mpg-C3N4 provided comparatively much higher reaction rate for $\mathbf{1 a}$ $\left(0.9 \mathrm{~mol} \mathrm{~g}_{\mathrm{Pd}}{ }^{-1} \mathrm{~h}^{-1}\right)$ (Table 1, entry 9) [124], that confirms the effectiveness of the strategy.

The continuous flow partial hydrogenation of 1-heptyne (2) to 1-heptene (2a), an additive for lubricants and a surfactant [125], was also reported using packed 2\% $\mathrm{Pd} @ \mathrm{Al}_{2} \mathrm{O}_{3}$ catalyst, showing $49 \%$ selectivity at $81 \%$ conversion under room temperature and 1 bar $\mathrm{H}_{2}$ (STY for $2 \mathrm{a}: 0.12 \mathrm{~kg} \mathrm{~L}^{-1} \mathrm{~h}^{-1}$ ), with no detectable signs of deactivation over $6 \mathrm{~h}$ reaction time [126].

\section{2-Methyl-3-butyn-2-ol and 3-methyl-1-pentyn-3-ol}

The catalytic partial hydrogenation reaction of 2-methyl-3butyn-2-ol (3) is an in-depth studied process, mainly because the alkene product (3a) is an important intermediate for the industrial synthesis of vitamins (A, E), as well as a variety perfumes $[127,128]$. The current manufacturing process is based on the Lindlar or other Pd-based heterogeneous catalysts under batch conditions. Yields of the desired product are in the range of $95-97 \%$, however, with fast catalyst deactivation due to degradation of the support or sintering of metal particles $[129,130]$.

Reports exist on the partial hydrogenation of $\mathbf{3}$ under continuous flow. Best results in terms of alkene yield (89\%) were reported for a capillary microreactor (10 m length, $250 \mu \mathrm{m}$ i.d., $110 \mathrm{~nm}$ film thickness) operating under annular two-phase flow regime, and whose inner walls were coated with a bimetallic $\mathrm{Pd}_{25} \mathrm{Zn}_{75}$ catalyst onto mesoporous $\mathrm{TiO}_{2}$ (Table 1 , entry 10 ). Selectivity could be further improved (97\%) by addition of harmful pyridine [131]. The rather systematic kinetic study showed the significant selectivity increase (ca. 10\%) by addition of $\mathrm{Zn}$ to the monometallic Pd catalysts, even at high substrate concentrations (up to $0.45 \mathrm{M}$ ). Selectivity enhancement could be attributed to a Pd site-isolation effect, similar to that found in Lindlar catalysts, which reduces the number of multiple interactions of the adsorbed intermediate alkene with active hydrogen species. It must be noted, however, the low STY value provided by this reactor type (less than $0.01 \mathrm{~kg} \mathrm{~L}^{-1} \mathrm{~h}^{-1}$ ) due to the low substrate fed allowed (max. $14 \mu \mathrm{L} \mathrm{min}{ }^{-1}$ ). A lower selectivity was observed for the corresponding batch setup that was justified in terms of a slightly different concentration of active sites in the catalysts, as a result of the different preparation procedures. Similar findings were observed for an analogous $\mathrm{Pd} @ \mathrm{TiO}_{2}$ capillary reactor (annular flow), which showed ca. $15 \%$ higher selectivity compared to the corresponding batch system, although under slightly different reaction conditions [132]. The result was attributed to the shorter contact time between reagent and catalyst in that case.

In a different approach, PdNP were immobilized onto an opencell macroporous (10 $\mu \mathrm{m}$ pore size), polymeric borate monolith, that was grown in situ within the walls of a commercial, tubular glass reactor (MonoBor, reactor volume $176 \mu \mathrm{L}$, Figure 5) [133]. The monolithic support was specifically designed to (a)

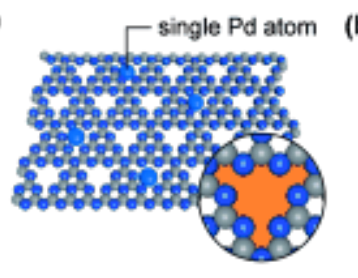

(b)

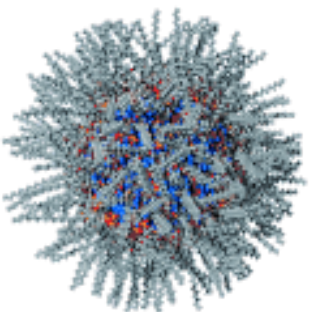

(c)

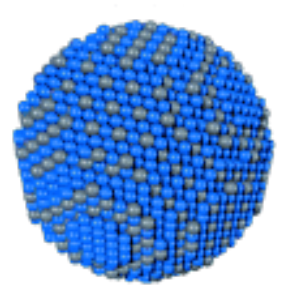

(d)

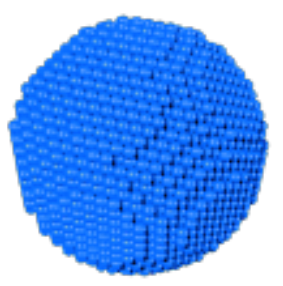

Figure 4: Structure of Pd@mpg-C3N4 (a), $\mathrm{Pd}(\mathrm{HHDMA}) @ \mathrm{C}(\mathrm{b}), \mathrm{Pd}(\mathrm{Pb}) @ \mathrm{CaCO}_{3}$ (c) and $\mathrm{Pd} @ \mathrm{Al}_{2} \mathrm{O}_{3}$ (d) catalysts. The structures depict the increasing size of the active ensemble, from a single Pd atom (a) to a bare PdNP of approximately 800 atoms (d). The inset in (a) shows a characteristic six-fold cavity (orange) in the carbon nitride structure. $\mathrm{C}$ light grey, $\mathrm{N}$ dark blue, $\mathrm{O}$ red, $\mathrm{Pb}$ grey, Pd light blue. Adapted with permission from [122], ( $)$ 2015 John Wiley and Sons. 
allow for the immobilization of Pd particles at non-coordinating borate sites within a rigid, highly-cross linked solid matrix (Figure 6) [134,135]. Under mild conditions (294 K, 1.4 bar $\mathrm{H}_{2}$ ), alkene $3 \mathrm{a}$ was obtained with good yield (93.9\% sel. at $92 \%$ conv.) and productivity $\left(1.52 \mathrm{~kg} \mathrm{~L}^{-1} \mathrm{~h}^{-1}\right.$ ) (Table 1 , entry 11) [136]. The latter value was attributed to the macroporosity and to the poor swelling volume of the support material, which allow for high flow rates to be attained with low backpressure evolution (methanol solution $0.1 \mathrm{M}, 0.6 \mathrm{~mL} \mathrm{~min}^{-1}$, $\mathrm{H}_{2}$ pressure drop 0.4 bar).

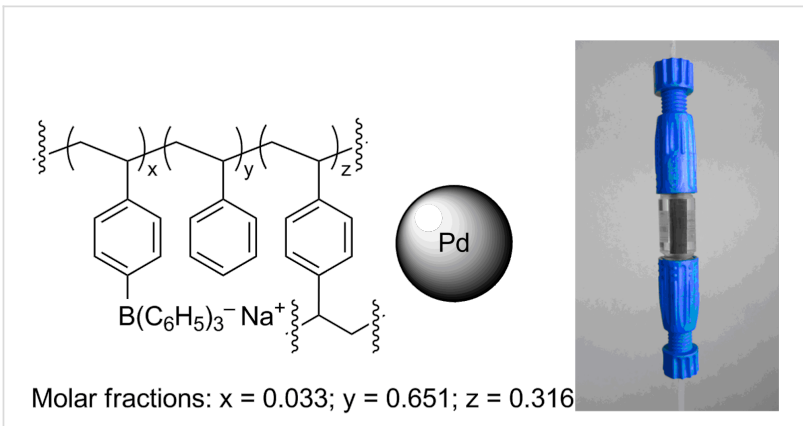

Figure 5: Sketch of composition (left) and optical image of Pd@MonoBor monolithic reactor (right). Adapted with permission from [136], @ 2013 Elsevier.

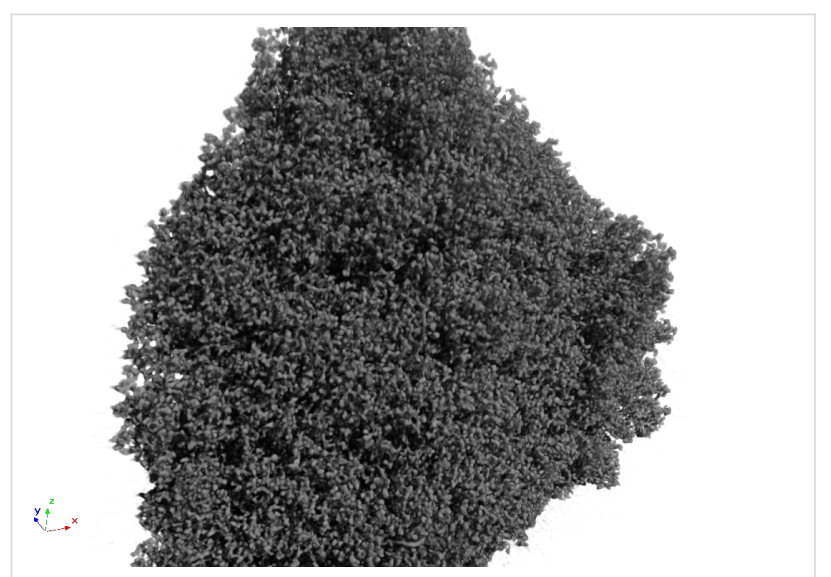

Figure 6: X-ray tomography 3D-reconstruction image of MonoBor [133]. Unpublished image from the authors.

The highest productivity in the continuous partial hydrogenation of 3 ( $82.3 \mathrm{~mol} \mathrm{~g}_{\mathrm{Pd}}{ }^{-1} \mathrm{~h}^{-1}$, Table 1 , entry 12$)$, was obtained using a packed-bed catalyst based on PdNP onto the outer surface of titanate nanotubes (Figure 7), that was justified in terms of both accessibility of Pd sites and high permeability of the packed 1D tubular material (weight hourly space velocity, $\mathrm{g}_{\text {substrate }} \mathrm{g}_{\text {catalyst }}{ }^{-1} \mathrm{~h}^{-1}$ ca. $11088 \mathrm{~h}^{-1}$ ) [137,138]. In fact, much lower efficiency was observed under analogous flow conditions using Pd immobilized into the pores of conventional mesoporous powder titania.

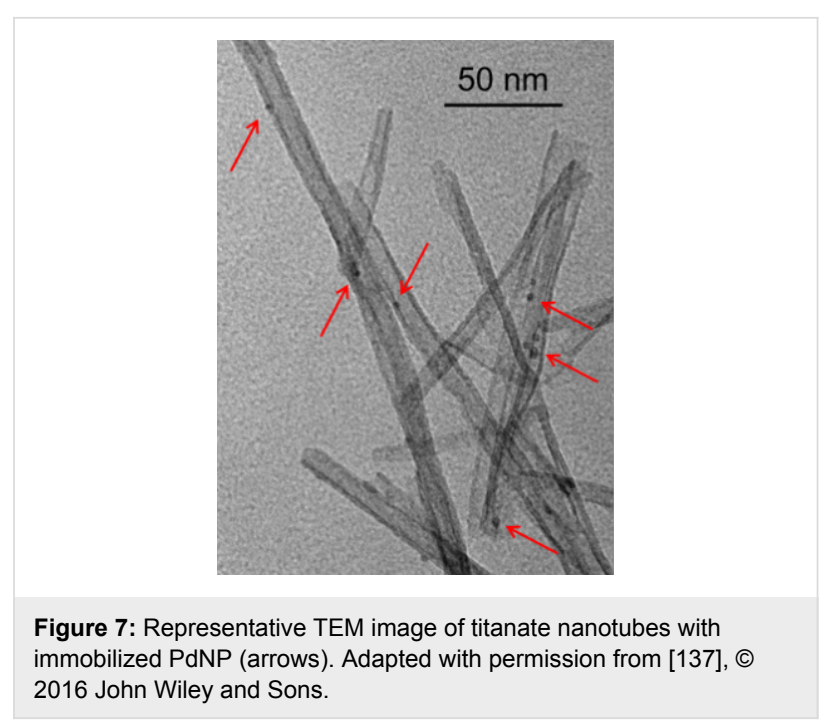

Analogous benefits in liquid phase flow operations were obtained by using nanostructured fibrous materials, that was attributed to the enhanced mass transfer of the one-dimensional packed support [139]. It is worth noticing that this result was obtained as a consequence of the so-called "Rational Catalyst Design" approach [140], applied to the hydrogenation of 2-methyl-3-butyn-2-ol as a case study [29]. In this approach, an optimized catalyst was designed by the integration of the catalyst performances at increasing length scales, from the nanoscale (active metal nanoparticles), to the mesoscale (support) and macroscale (reactor). Thus, after identification of the optimal shape and size of PdNP for the hydrogenation of $\mathbf{3}$, the ex-situ particles were deposited onto a $\mathrm{ZnO} /$ Sintered Metal Fibers support, having selected this material for its excellent mass transfer properties. The catalyst was then integrated into a bubble column flow reactor with staged catalytic layers, showing two order magnitude higher productivity compared to Lindlar catalyst [141].

Low to moderate yields and productivities for $\mathbf{3 a}$ were reported by using conventional packed-bed catalysts, either HHDMAmodified (Table 1, entries 13, 14) [121], Lindlar (Table 1, entry 15) or non-palladium based (Table 1, entries 16, 17) [123]. As above discussed for $\mathbf{1}$, single-atom catalysts resulted in high productivity, however, direct comparison of product yield with other systems is not possible due to insufficient experimental data (Table 1, entry 18) [122]. PdNP onto hybrid zirconia/ polyvinyl alcohol matrix (NKZPD) were also described, providing 3a in moderate selectivity (60\%) at full conversion and mild conditions (Table 1, entry 19) [142].

The partial hydrogenation reaction of the parent alkyne 3-methyl-1-pentyn-3-ol (4) was also reported under continuous flow. Similarly to what described above for $\mathbf{1}$ and $\mathbf{3}$, the hydro- 
genation of $\mathbf{4}$ to $\mathbf{4 a}$ was investigated in detail by comparing the selectivity of diverse Pd packed-bed catalysts at the same substrate conversion level (30\%). The study confirmed the efficiency of the catalysts to decrease in the order Pd(HHDMA)@C $>$ Pd(HHDMA)@TiS > Lindlar > Pd@ $\mathrm{Al}_{2} \mathrm{O}_{3}$ (from 100 to $67 \%$ ) [121]. This selectivity trend was explained in terms of both adsorption mode on and relative accessibility to Pd active sites, depending on surface potentials and hindrance of modifiers, on the basis of density functional theory and molecular dynamics calculations. The rationale was summarized in the so-called thermodynamic selectivity concept, that is "a selective catalyst involves strong adsorption of the alkyne and a low stability to the adsorbed alkene" [121]. In bare Pd catalysts, such as $\mathrm{Pd} @ \mathrm{Al}_{2} \mathrm{O}_{3}$, or in alloyed Pd catalysts, such as Lindlar, the intermediate alkene is strongly adsorbed on Pd surface (exothermic process), thereby favouring further reaction with $\mathrm{H}_{2}$ and reducing selectivity. In bulky ligand-modified catalysts, such as Pd(HHDMA)@C, the adsorption process is slightly endothermic and selectivity is enhanced.

A high yield of $4 a(78 \%)$ was also obtained by means of a capillary microreactor consisting in a mesoporous $\mathrm{Al}_{2} \mathrm{O}_{3}$-coated commercial fused-silica column with embedded PdNP (530 $\mu \mathrm{m}$ i.d., $25 \mathrm{~cm}$ length, $6 \mu \mathrm{m}$ thick layer) (Table 1, entry 20) [143]. Experiments were performed in a segmented flow regime $\left(\mathrm{H}_{2}\right.$ gas/ethanol solution), so that the flow pattern enhanced the contact with the catalyst on the wall and minimize diffusion limits (Figure 2). Without bubbles, the yield of 4 a would have been ca. $57 \%$ at the same residence time. The catalyst was used for weeks without significant deactivation.

\section{1-Cyclohexyl-2-methyl-3-butyn-1-ol}

In the course of their studies on diastereoselective chain-elongation reactions, Ley and Baxendale reported the hydrogenation of (1R,2R)-1-cyclohexyl-2-methyl-3-butyn-1-ol (5), where the partial reduction of the triple bond is achieved in the presence of stereogenic centres [144]. The alkene 5a was obtained in 95\% yield, without compromising the starting diastereomeric ratio (4.3:1), using the Lindlar catalyst packed into a commercial H-Cube ${ }^{\circledR}$ apparatus under mild hydrogenation conditions (298 K, 10 bar $\mathrm{H}_{2}$, Table 1, entry 21).

\section{1,1-Diphenyl-2-propyn-1-ol}

High yields of alkene $\mathbf{6 a}$ were obtained by partial hydrogenation of 1,1-diphenyl-2-propyn-1-ol (6) using the monolithic Pd@MonoBor catalyst under smooth flow conditions (294 K, $84 \%$ selectivity at $85 \%$ conversion, Table 1 , entry 22) [136]. Neither significant catalyst efficiency decay over $8 \mathrm{~h}$ reaction period was detected (Figure 8), nor an evidence for Pd leaching in solution was provided by ICP-OES throughout the reaction. This finding was justified by the effective electrostatic stabiliza- tion of PdNP by the charged $-\mathrm{B}\left(\mathrm{C}_{6} \mathrm{H}_{4}\right)^{-}$groups onto the polymeric solid matrix. A small activity loss was attributed to poisoning by dimers and other byproducts adsorbed on the catalyst surface, as described for other batch Pd catalysts [145]. Under analogous conditions, Pd@TiNT gave 6a in comparable yield (69.4\%), although with remarkably higher productivity (for 6a: $20.0 \mathrm{~mol} \mathrm{~g}_{\mathrm{Pd}}^{-1} \mathrm{~h}^{-1}$ ) (Table 1, entry 23) [137], as previously outlined in the case of alkyne 3 .

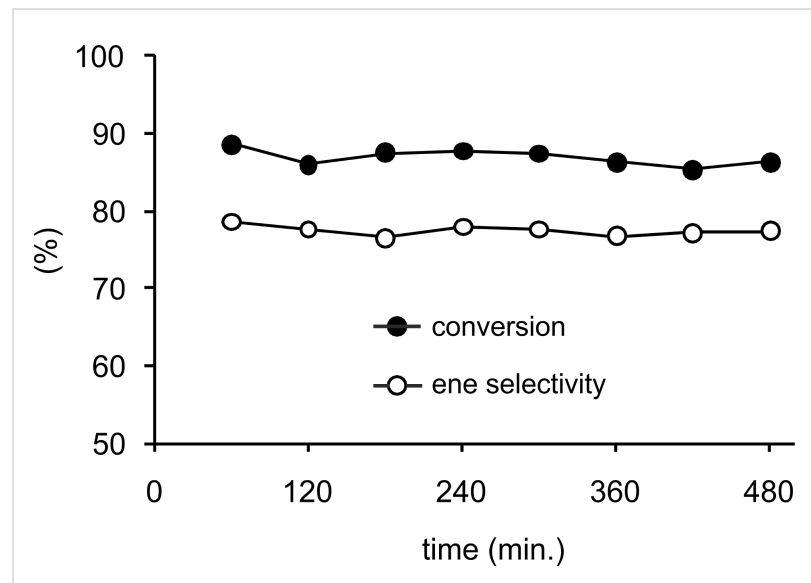

Figure 8: Conversion and selectivity vs. time-on-stream for the continuous-flow hydrogenation of 6 over Pd@MonoBor catalyst (methanol solution $0.16 \mathrm{~mL} \mathrm{~min}^{-1}, \mathrm{H}_{2} 1.00 \mathrm{~mL} \mathrm{~min}^{-1} @ 1.29$ bar, rt). Reprinted with permission from [136], @ 2013 Elsevier.

These latter results outperform those obtained at higher reaction temperatures using packed catalysts onto conventional supports, including Lindlar, $\mathrm{CeO}_{2} @ \mathrm{TiO}_{2}, \mathrm{Ag} @ \mathrm{SiO}_{2}$ and $\mathrm{Au} @ \mathrm{TiO}_{2}$ (Table 1, entries 24-27), although the data are not properly comparable because they refer to significantly lower conversion levels $(30-50 \%)[119,123]$. The partial hydrogenation of $\mathbf{6}$ to $\mathbf{6 a}$ under batch conditions was also described in $82-90 \%$ yield using phosphinated polymer incarcerated palladium catalysts [146].

The hydrogenation reaction of the bulky alkyne 1,1-diphenyl-2propyn-1-ol (6) provides an interesting discussion example on how the relationship between catalyst architecture and substrate hindrance affects catalyst activity, even if not directly related to continuous flow operation conditions. It was proposed that ligand-modified surfaces, such as Pd(HHDMA)@C, are threedimensional catalytic ensembles whose organic capping layer cannot be penetrated with ease by larger alkynes (Figure $4 b$ ) [121]. This justifies for the inactivity of $\operatorname{Pd}($ HHDMA)-type catalysts toward the hydrogenation of $\mathbf{6}$, while they are quite active in short-chain alkynes hydrogenation, e.g., 3 (Table 1, entries 13, 14) [123]. On the other hand, "naked" and $\mathrm{Pb}$-poisoned palladium surfaces are 2D catalytic architectures (Figure 4c,d), which are amenable of alkynes adsorption irre- 
spective of the chain length, thus resulting in high hydrogenation activity anyway. The selectivity is ruled by, e.g., site-isolation effects $(\mathrm{Pd}-\mathrm{Pd})$ in that case.

\section{Phenylacetylene}

The liquid-phase partial hydrogenation of phenylacetylene 7 was successfully achieved in the past using batch Pd catalysts $(0.15-5 \% \mathrm{wt})$, with typical $7 \mathrm{a}$ yields in the range of $60-70 \%$ $[147,148]$. More recently, a number of catalytic flow reactors were also described for this process. Best yields (94-100\%) were achieved using either 16\% $\mathrm{CeO}_{2} @ \mathrm{TiO}_{2}(100 \%)$ [119] or $\mathrm{Pd} @$ MonoBor catalyst [136], under 90 bar $\mathrm{H}_{2}$ and $413 \mathrm{~K}$ or 1.3 bar $\mathrm{H}_{2}$ and $294 \mathrm{~K}$, respectively (Table 1, entries 28, 29). As above reported for other substrates, best results in terms of productivity were provided by the monolithic and the titanate nanotubes-supported Pd catalysts (2.9-6.5 mol $\mathrm{g}_{\mathrm{Pd}}{ }^{-1} \mathrm{~h}^{-1}$, Table 1, entries 29, 30) [137]. Lower performances were observed using packed-bed catalysts and conventional support materials [123], an amorphous $\mathrm{Pd}_{81} \mathrm{Si}_{19}$ alloy catalyst in supercritical $\mathrm{CO}_{2}(76 \%$ sel. at $91 \%$ conversion, $358 \mathrm{~K})$ [149] or a capillary reactor (i.d. $250 \mu \mathrm{m}$ ) internally coated with Pd-doped mesoporous titania film (95\% sel. at $30 \%$ conversion, $323 \mathrm{~K}$ ) [150] (Table 1, entries 31-33).

The reduction of $\mathbf{7}$ to $\mathbf{7 a}$ was also reported by transfer hydrogenation using formic acid / triethylamine as hydrogen source and packed $\mathrm{Au} @ \mathrm{TiO}_{2}$ (rutile) catalyst [151]. An outstanding 99.7\% yield was achieved at $333 \mathrm{~K}$, corresponding to a productivity for $7 \mathbf{a}$ of $1.9 \mathrm{~mol} \mathrm{~g}_{\mathrm{Pd}}{ }^{-1} \mathrm{~h}^{-1}$ (Table 1, entry 34 ). This value was considerably higher (ca. 40\%) than that obtained for the batchtype reaction under identical conditions. The selectivity toward 7a was retained during the continuous operations, while a progressive decrease of conversion from $99 \%$ to $85 \%$ was observed after $3 \mathrm{~h}$ time on stream, that was partially recovered by treatment with acetone.

\section{1-Bromo-4-ethynylbenzene and 1-ethynyl-4- nitrobenzene}

The hydrogenations of 7, 1-bromo-4-ethynylbenzene (8) and 1-ethynyl-4-nitrobenzene (9) were also reported with modest yields to $7 \mathbf{a}(56 \%),(8 \mathbf{a})(21 \%)$ and (9a) (21\%), eventually with the addition of triethylamine, using a packed-bed multichannel catalytic reactor. The catalyst was based on PdNP onto trimodal (micro, meso), hierarchical porous synthetic carbon [152]. No catalyst deactivation was detected over 5 hours continuous runs $\left(333 \mathrm{~K}, 1\right.$ bar $\left.\mathrm{H}_{2}\right)$.

A perusal of Table 1 shows that identification of the most versatile partial hydrogenation flow system for terminal alkynes, either catalyst or reactor, is prevented by significant substrate specificity, lack of experimental data or choice of parameter to be compared either selectivity, productivity or STY. As representative example for selected catalysts and substrates 3, 6 and 7, one can infer that $\mathrm{CeO}_{2} @ \mathrm{TiO}_{2}$ usually provides better selectivity compared to other systems with strong substrate dependence (such as Pd(HHDMA)@C, see above discussion) (Figure 9). However, data are not available at the same conversion level, yet not directly comparable. Comparison in terms of, e.g., productivity is limited due to the same reason.

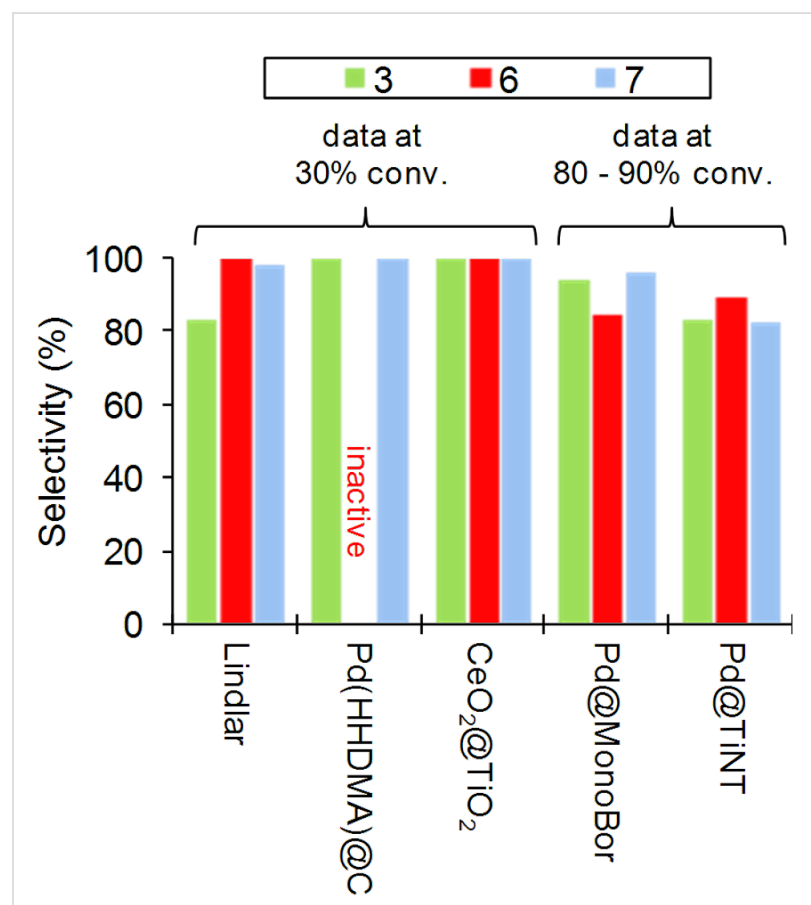

Figure 9: Continuous-flow hydrogenation of 3, 6 and $\mathbf{7}$ over different catalytic reactor systems. Data from refs. [119,121,123,136,137].

\section{Hydrogenation of internal alkynes}

Compared to terminal alkynes, the partial hydrogenation reaction of internal alkynes is more challenging and intriguing owing to the stereoselectivity involved (usually cis) and to the large use of the products thereof in the fine-chemical industry. Most significant substrates examined in the literature under the continuous-flow catalysis conditions are reported in Scheme 3.

\section{3-Hexyne}

Analogously to the earlier discussed hydrogenation of 1-hexyne (see above), the continuous flow, partial hydrogenation of 3-hexyne (10) to cis-3-hexene (10a) has been extensively examined by comparing the efficiency of various packed-bed supported catalysts $[119,121,123]$. In all cases, irrespective of the metal or the support, the catalysts yielded the cis-alkene product with selectivity $\geq 89 \%$, with the exception $\mathrm{Pd} / \mathrm{Al}_{2} \mathrm{O}_{3}$ (Table 2, entry 1), in line with the previous observation on the selectivity to 1 -hexene. The trend regarding catalysts efficiency 


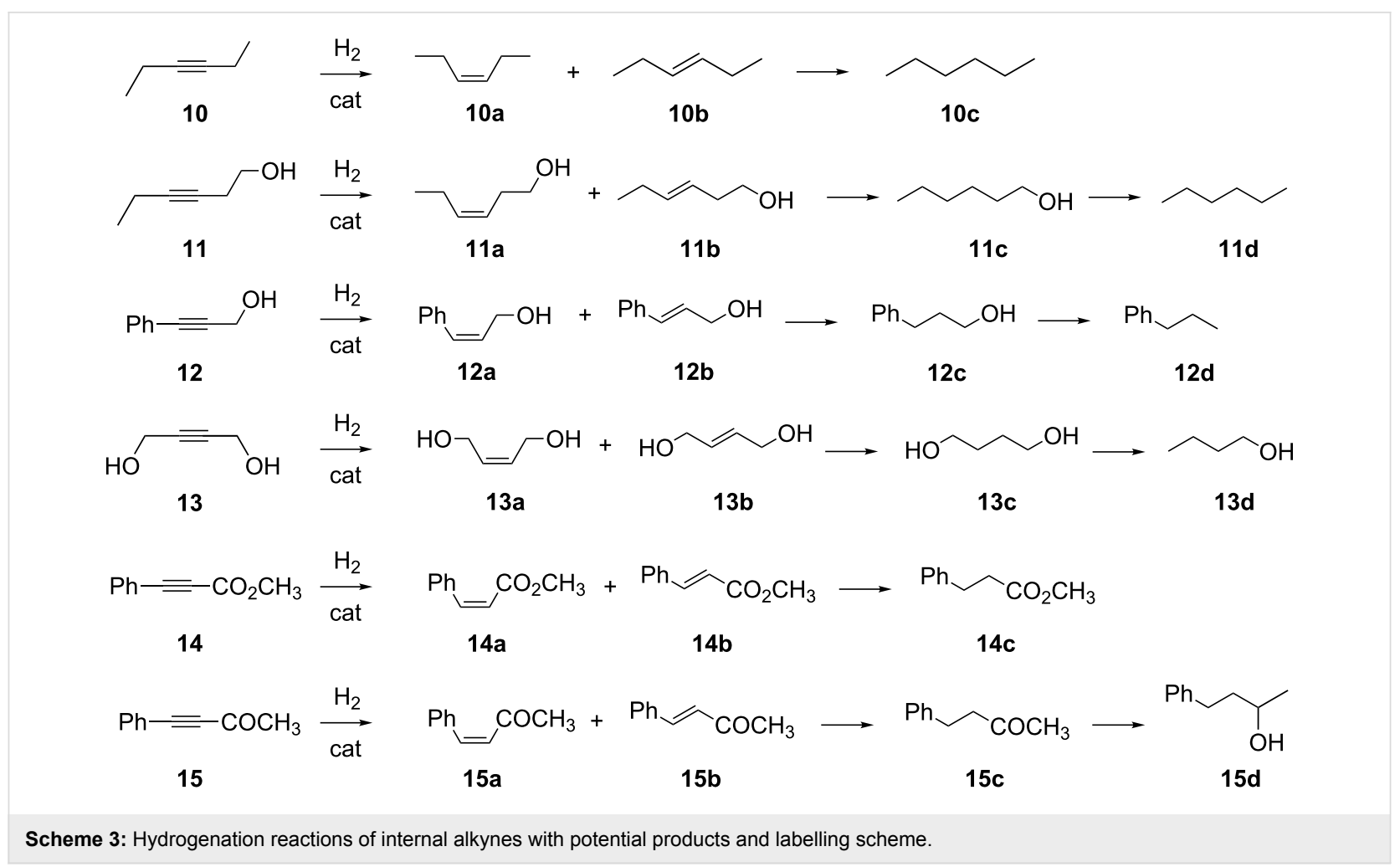

was also very similar. High yields of 10a $(>87 \%)$ were observed for the Lindlar and the $\mathrm{TiO}_{2}$-supported ceria catalysts, with a better productivity for the former (Table 2, entries 2, 3). All the other catalysts, including the HHDMA ligand modifiedPd one (Table 2, entries 4, 5) and the Ag and Au-based catalysts (Table 2, entries 7,8) showed comparable selectivity, although at a lower conversion level. No data regarding the longterm catalysts stability were provided. Exceptionally high productivity was once again obtained for 10a by the isolated $\mathrm{Pd}$ atoms catalyst Pd@mpg-C3N4 (11.3 mol g $\mathrm{Pd}^{-1} \mathrm{~h}^{-1}$, Table 2, entry 6) [123].

\section{3-Hexyn-1-ol and 3-phenyl-2-propyn-1-ol}

The cis-partial hydrogenation product of 3-hexyn-1-ol (11), the so-called leaf alcohol 11a, is an important product widely used as fragrance or perfumes component $[153,154]$. It is industrially obtained with a production volume of $400 \mathrm{t} / \mathrm{y}$ in ca. $96 \%$ selectivity at $99 \%$ conversion by means of a conventional Lindlar-based batch process $[155,156]$. Several systems have been reported on the lab scale for the catalytic hydrogenation of 11 under continuous-flow conditions.

An accurate study was carried out using the Pd@MonoBor monolithic catalyst [136], showing how the subtle effect of fine adjustments of concurrent flows of methanol substrate solution and $\mathrm{H}_{2}$ gas may tune the conversion and selectivity of the process. As anticipated for similar hydrogenation systems, under the same solution flow rate (i.e., keeping constant the residence time $\tau$ ), an increase in the $\mathrm{H}_{2}$ flow rate (i.e., the $\mathrm{H}_{2}$ / substrate molar ratio) resulted in a higher conversion and in a lower ene- and $Z / E$ selectivity (Figure 10a). An increase in the solution flow rate (i.e., a decrease in $\tau$ ) under a constant the $\mathrm{H}_{2}$ / substrate molar ratio resulted in a conversion decrease, but in a selectivity enhancement (Figure 10b). A reproducible selectivity/conversion diagram could be drawn on this basis, as reported in Figure 10c. Best compromise results between selectivity and conversion resulted in $87 \%$ 11a yield (95\% ene selectivity, of which $93 \%$ cis, at $99 \%$ conversion) under mild conditions $\left(294 \mathrm{~K}\right.$, residence time $42 \mathrm{~s}$, ratio $\mathrm{H}_{2} / \mathbf{1 1}=2.7$, Table 2, entry 9).Pd@MonoBor is the first catalyst reported for the production of 11a under continuous flow showing selectivity comparable to that of the industrial process, with additional benefits of lower noble metal content, no presence of toxic $\mathrm{Pb}$ or other additives [157]. The performance of Pd@MonoBor also compared favourably with that of other conventional batch systems $[158,159]$. Selectivity enhancement in the batch alkynes semi-hydrogenation was reported using egg-shell type catalyst. This was attributed to the short contact time of the intermediate alkene with the metal located on the catalyst surface, so that the alkene is quickly removed from the active phase with no possibility of further reduction [160]. A similar effect was invoked for Pd@MonoBor, whose site accessibility is hampered by the low swelling of the support in methanol solvent. Better swelling would allow the solvent to diffuse thor- 
Table 2: Representative continuous flow catalytic processes for liquid-phase partial hydrogenation of internal alkynes

\begin{tabular}{|c|c|c|c|c|c|c|c|c|c|c|c|}
\hline \multirow[t]{2}{*}{ entry } & \multirow[t]{2}{*}{ alkyne } & \multirow[t]{2}{*}{ reactor $^{a}$} & \multirow[t]{2}{*}{ catalyst } & \multirow{2}{*}{$\begin{array}{c}T \\
(\mathrm{~K})\end{array}$} & \multirow{2}{*}{$\begin{array}{c}\text { conv. }^{\mathrm{b}} \\
(\%)\end{array}$} & \multicolumn{2}{|c|}{ selectivity } & \multirow{2}{*}{$\begin{array}{l}\text { yield }^{e} \\
(\%)\end{array}$} & \multirow{2}{*}{$\begin{array}{c}\operatorname{prod}^{\mathrm{f}, \mathrm{g}} \\
\left(\mathrm{mol} \mathrm{g}_{\mathrm{M}}^{-1} \mathrm{~h}^{-1}\right)\end{array}$} & \multirow{2}{*}{$\begin{array}{c}S T Y^{f} \\
\left(\mathrm{~kg} \mathrm{~L}^{-1} \mathrm{~h}^{-1}\right)\end{array}$} & \multirow[t]{2}{*}{ ref. } \\
\hline & & & & & & $\begin{array}{c}\text { ene }^{\mathrm{c}} \\
(\%)\end{array}$ & $\begin{array}{c}Z / E^{d} \\
(\%)\end{array}$ & & & & \\
\hline 1 & 10 & PB & 1.0\% Pd@ $\mathrm{Al}_{2} \mathrm{O}_{3}$ & 293 & $30^{\mathrm{h}}$ & $-i$ & 53 & 15.9 & 0.3 & 0.07 & [121] \\
\hline 2 & 10 & PB & $5 \% \mathrm{Pd}(\mathrm{Pb}) @ \mathrm{CaCO}_{3}$ & 293 & $93^{h}$ & $-i$ & $94^{\mathrm{j}}$ & 87.4 & 3.1 & 1.73 & [119] \\
\hline 3 & 10 & PB & $16 \% \mathrm{CeO}_{2} @ \mathrm{TiO}_{2}$ & 413 & $93^{k}$ & $-i$ & 100 & 93.0 & $<0.1$ & 0.18 & [119] \\
\hline 4 & 10 & PB & 0.6\% Pd(HHDMA)@C & 293 & $30^{\mathrm{h}}$ & $-i$ & 97 & 29.1 & 0.8 & 0.13 & [121] \\
\hline 5 & 10 & PB & 0.5\% Pd(HHDMA)@TiS & 293 & $30^{\mathrm{h}}$ & $-i$ & 100 & 30.0 & 0.9 & 0.14 & [121] \\
\hline 6 & 10 & PB & 0.5\% Pd@mpg-C3N4 & 343 & $-{ }^{\mathrm{i}, \mathrm{I}}$ & $-\mathrm{i}$ & 90 & $-\mathrm{i}$ & 11.3 & 1.64 & {$[122]$} \\
\hline 7 & 10 & PB & $1.3 \% \mathrm{Ag} @ \mathrm{SiO}_{2}$ & 373 & $30^{m}$ & $-i$ & 89 & 26.7 & 0.1 & 0.12 & [123] \\
\hline 8 & 10 & PB & 1\%Au@ $\mathrm{TiO}_{2}$ & 373 & $30^{\mathrm{m}}$ & $-i$ & 94 & 28.2 & 0.1 & 0.13 & [123] \\
\hline 9 & 11 & $\mathrm{M}$ & 0.67\% Pd@MonoBor & 294 & $>99^{n}$ & 95 & 93 & 87.5 & 6.8 & 0.75 & {$[136]$} \\
\hline 10 & 11 & PB & 0.5\% Pd@TiNT & 294 & $88^{n}$ & 94 & 93 & 76.9 & 40.6 & 4.24 & [137] \\
\hline 11 & 11 & PB & 0.73\% Pd@TiO 2 & 294 & $84^{n}$ & 80 & 85 & 57.1 & 19.2 & 0.20 & [137] \\
\hline 12 & 11 & PB & 1.2\% Pd@SiO 2 & 294 & $40^{n}$ & 87 & 93 & 32.4 & 7.1 & 1.43 & [137] \\
\hline 13 & 11 & PB & $5 \% \mathrm{Pd}(\mathrm{Pb}) @ \mathrm{CaCO}_{3}$ & 294 & $99^{n}$ & 64 & 62 & 39.4 & 0.2 & 0.10 & [136] \\
\hline 14 & 11 & PB & 1.25\% Pd/Dowex-Li & 294 & $75^{n}$ & 80 & 89 & 53.4 & 2.3 & 0.73 & [161] \\
\hline 15 & 11 & PB & 5\% Pd@C & 294 & $94^{\mathrm{n}}$ & 22 & 81 & 16.8 & 0.9 & 0.16 & [140] \\
\hline 16 & 11 & PB & 0.1\% Pd@NKZPDB-5 & 294 & $99^{n}$ & 83 & 83 & 68.2 & 11.4 & 0.43 & [141] \\
\hline 17 & 11 & M & 1.3\% Pd@ $\mathrm{SiO}_{2}$ monolith & 298 & $85^{\mathrm{n}}$ & 80 & 80 & 54.4 & 0.5 & 0.17 & [162] \\
\hline 18 & 11 & M & $0.2 \% \mathrm{Pd} @ \mathrm{TiO}_{2}$ monolith & 294 & $61^{\mathrm{n}}$ & 63 & 87 & 33.7 & 1.8 & 0.51 & {$[163]$} \\
\hline 19 & 12 & M & 0.67\% Pd@MonoBor & 294 & $96^{n}$ & 79 & 95 & 71.9 & 0.8 & 0.12 & [136] \\
\hline 20 & 13 & M & 0.67\% Pd@MonoBor & 294 & $93^{n}$ & 75 & 100 & 70.2 & 3.3 & 0.32 & [136] \\
\hline 21 & 13 & $\mathrm{HC}$ & $0.5 \% \mathrm{Pd} @ \mathrm{Al}_{2} \mathrm{O}_{3}$ & 328 & $90^{\circ}$ & 99 & 100 & 89.8 & 0.7 & $-i$ & [170] \\
\hline 22 & 13 & PB & $0.5 \% \mathrm{Pd} @ \mathrm{Al}_{2} \mathrm{O}_{3}$ & 328 & $90^{\circ}$ & 94 & 93 & 78.7 & 1.0 & $-i$ & {$[170]$} \\
\hline 23 & 13 & PB & 5\% Pd@C & 323 & $92^{p}$ & 100 & 97 & 89.6 & $--^{i}$ & $--^{i}$ & [172] \\
\hline 24 & 14 & M & 0.67\% Pd@MonoBor & 294 & $90^{n}$ & 91 & 96 & 79.2 & 6.1 & 1.09 & [136] \\
\hline 25 & 15 & $M$ & 0.67\% Pd@MonoBor & 294 & $92^{n}$ & 93 & 50 & 42.8 & 1.1 & 0.17 & {$[136]$} \\
\hline
\end{tabular}

aReactor type: C, capillary; PB, packed-bed; HC, honeycomb; M, monolithic. bSubstrate conversion. "Selectivity to the alkene product, e.g.,

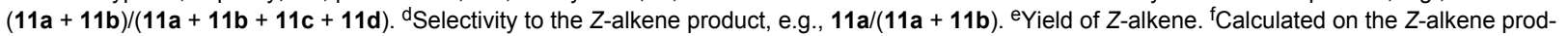

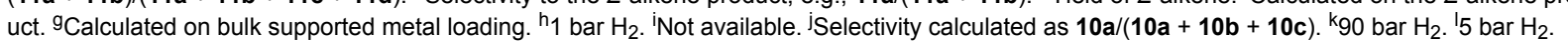
$\mathrm{m}_{10}$ bar $\mathrm{H}_{2} .{ }^{\mathrm{n}} 1-2.7$ bar $\mathrm{H}_{2}$ K. ${ }^{\circ} 2$ bar $\mathrm{H}_{2} .{ }^{\mathrm{p}} 10$ bar $\mathrm{H}_{2}$.

oughly the support, thereby producing a larger number of substrate-catalyst interactions, which results in lower alkene selectivity. The reaction using Pd@MonoBor was monitored for 14 h time-on-stream, showing no appreciable decay of conversion or selectivity (Figure 11). The catalyst could be reused several times with neither significant activity drop nor palladium leaching in solution detected.

Under comparable 11a yield (76.9\%), better productivity was shown by the packed Pd@titanate nanotubes catalyst (for 11a: $40.6 \mathrm{~mol} \mathrm{~g}_{\mathrm{Pd}}^{-1} \mathrm{~h}^{-1}$, Table 2, entry 10) [137], analogously to what above described for the partial hydrogenation of $\mathbf{3}$. As for
Pd@MonoBor, the high selectivity observed in this case was attributed to the short contact time of the intermediate alkene with the Pd sites located onto the outer surface of the catalyst. Indeed, an excellent product yield was obtained for short residence times (13 s), that suggests a high contribution to catalytic activity by easy accessible PdNP. No catalyst efficiency decay was observed over $6 \mathrm{~h}$ time-on-stream.

Worse performances were shown by other Pd packed-bed catalysts using conventional support materials, including mesoporous titania powder, mesoporous Davisil silica, Lindlar, geltype Dowex resin, carbon (Table 2, entries 11-15), with the 
a) Fixed residence time $\tau 42 \mathrm{~s}$

$\mathrm{H}_{2}$ : 11 mol ratio

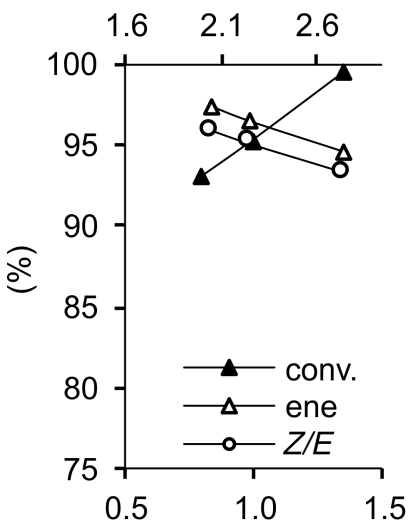

$\mathrm{H}_{2}$ flow $\left(\mathrm{ml} \mathrm{min}^{-1}\right)$ b) Fixed $\mathrm{H}_{2}$ : 11 molar ratio 2.7

c)

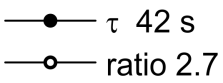

$\tau(\mathrm{s})$

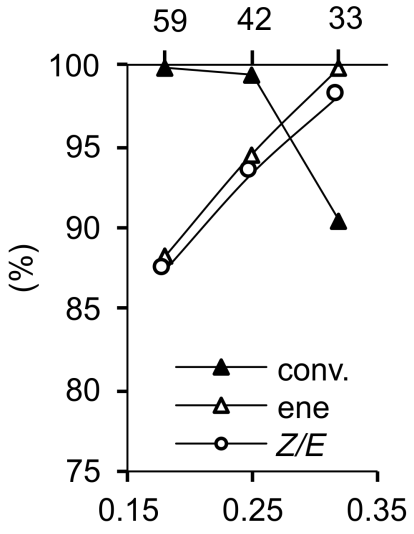

Solution flow $(\mathrm{ml} \mathrm{min}-1)$

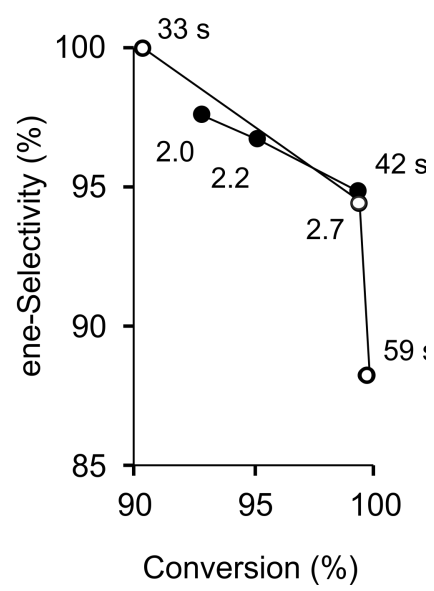

Conversion (\%)

Figure 10: Continuous-flow hydrogenation of 11 over Pd@MonoBor catalyst. a) Conversion and selectivity as a function of $\mathrm{H}_{2}$ flow rate and $\mathrm{H}_{2}$ :11 molar ratio under fixed residence time т $42 \mathrm{~s}$ (solution flow rate $0.25 \mathrm{~mL} \mathrm{~min}^{-1}$ ). b) Conversion and selectivity as a function of solution flow rate and residence time under fixed $\mathrm{H}_{2}: 11$ molar ratio 2.7. c) selectivity/conversion diagram at: $\circ$ fixed $\mathrm{H}_{2}: 11$ ratio $=2.7$ and residence time $33-59 \mathrm{~s}$, - fixed residence time $42 \mathrm{~s}$ and $\mathrm{H}_{2}: 11$ ratio range 2.0-2.7. Data from ref. [136].

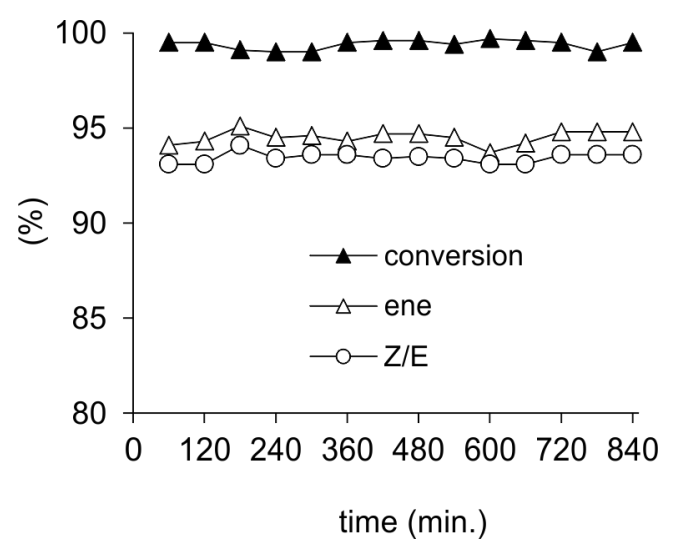

Figure 11: Conversion and selectivity vs time-on-stream for the continuous-flow hydrogenation of 11 over Pd@MonoBor catalyst (methanol solution $0.25 \mathrm{~mL} \mathrm{~min}{ }^{-1}, \mathrm{H}_{2} 1.35 \mathrm{~mL} \mathrm{~min}^{-1} @ 2.2$ bar, rt). Reprinted with permission from [136], () 2013 Elsevier.

latter showing the highest rate of over-hydrogenation to 1-hexanol (11c, yield $>70 \%$, Figure 12) [136,137,161]. Good yield $(68.2 \%)$ and productivity $\left(11.4 \mathrm{~mol} \mathrm{~g}_{\mathrm{Pd}}{ }^{-1} \mathrm{~h}^{-1}\right)$ of $\mathbf{1 1 a}$ were obtained by packing pellets of a hybrid zirconia/polyvinylalcohol matrix with embedded PdNP (Table 2, entry 16) [142].

Catalysts based on PdNP immobilized into the mesopores of hierarchically ordered meso- and macroporous inorganic silica [162] and titania monoliths [163] (Figure 13), were also reported showing moderate yields and remarkable catalyst stability over a period of $24 \mathrm{~h}$ (Table 2 , entries 17,18$)$.

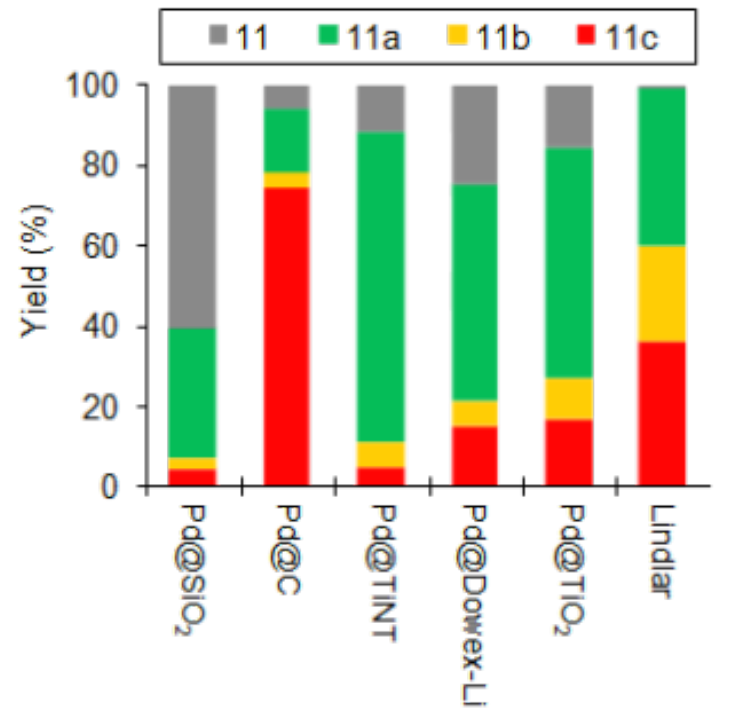

Figure 12: Continuous-flow hydrogenation reaction of 11 over packedbed catalysts. Adapted with permission from [137], @ 2016 John Wiley and Sons.

The heterogeneous hydrogenation of the parent alkyne substrate 3-phenyl-2-propyn-1-ol (12) is of interest because the corresponding alkene, the cinnamyl alcohol $(\mathbf{1 2 a}+\mathbf{1 2 b})$, is used in the formulation of perfumes and other personal care products [164]. The highest selectivity so far reported in batch conditions was observed using dendron-stabilized PdNP catalysts with quinoline additives ( $97 \%$ ene, $98 \%$ Z) [165]. The only ex- 


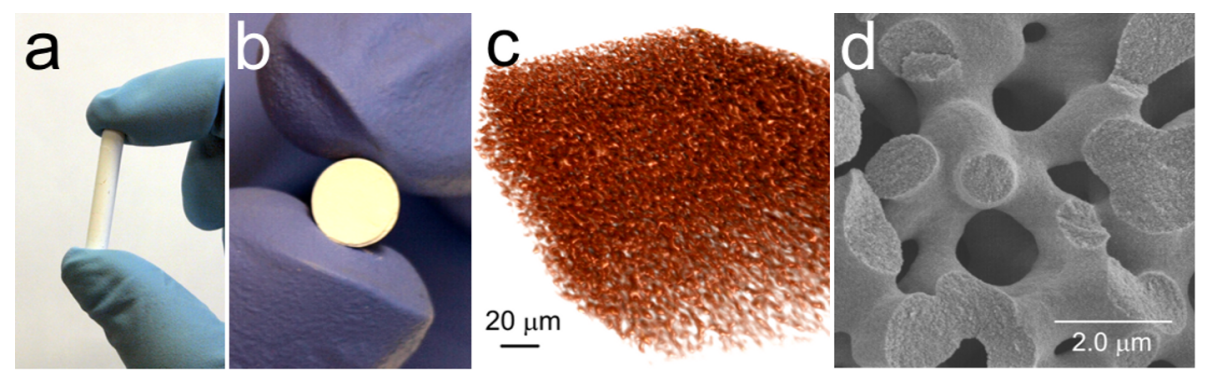

Figure 13: Images of the bimodal $\mathrm{TiO}_{2}$ monolith with well-defined macroporosity: (a, b) optical; (c) X-ray tomography; (d) scanning electron microscopy. Reprinted with permission from [163], () 2012 American Chemical Society.

ample described under continuous flow used the Pd@monobor catalysts to achieve a $96 \%$ conversion and $79 \%$ selectivity to alkene and $95 \%$ to the $Z$ isomer (Table 2, entry 19) [136].

\section{2-Butyne-1,4-diol}

From an industrial point of view, there is a great interest in the selective semi-hydrogenation reaction of 2-butyne-1,4-diol (13) under flow conditions, since cis-2-butene-1,4-diol (13a) is an important intermediate in the synthesis of antibiotics, vitamins $\mathrm{A}$ and $\mathrm{B}_{6}$, several insecticides and antitumoral chemicals [166]. Currently, 13a is manufactured from $\mathbf{1 3}$ in ca. 5000 t/y by a batch process under elevated pressures and/or temperatures, using $0.5 \% \mathrm{Pd} @ \mathrm{Al}_{2} \mathrm{O}_{3}$ catalysts doped with $\mathrm{Cd}, \mathrm{Zn}, \mathrm{Bi}$ or Te [167]. On the laboratory scale, it is obtained with high selectivity ( $70-99 \%$ at $80-90 \%$ conversion) by the same route, using various supports and additives (including $\mathrm{Zn}, \mathrm{NH}_{3}$, pyridine, $\mathrm{KOH})[168,169]$.

Under the conditions of continuous-flow catalysis, Pd@MonoBor provided 13a in moderate yields (70.2\%) and high productivity $\left(3.3 \mathrm{~mol} \mathrm{~g}_{\mathrm{Pd}}^{-1} \mathrm{~h}^{-1}\right)$ at $294 \mathrm{~K}$, with the formation of butyraldehyde byproducts in addition to the saturated alcohols $\mathbf{1 3 c}$ and 13d, as commonly reported in the literature for this substrate (Table 2, entry 20) [136].

Better product purity, but lower productivity, was observed using conventional flow reactors at higher reaction temperatures. Thus, $\mathrm{Pd} @ \mathrm{Al}_{2} \mathrm{O}_{3}$ catalysts, either as wash-coated honeycomb or as egg-shell particles packed-bed setups, resulted in a high ene- and cis selectivity $(>93 \%)$ at $90 \%$ conversion at $328 \mathrm{~K}$ (Table 2, entries 21, 22) [170]. In that study, a comparison between honeycomb and packed-bed systems was carried out introducing the additional variables of cocurrent downflow contactor (CDC) and a trickle bed reactor (TBR) setups, that hinders a proper rationale of efficiency differences. However, the superior performance of honeycombs was highlighted both in terms of selectivity and productivity to 13a. Supported $\mathrm{Pd} @ \mathrm{Al}_{2} \mathrm{O}_{3}$ was also reported by the group of A. N. Tsoligkas where a circular capillary reactor was used in co-current downflow mode under Taylor flow regime (also known as slug and segmented flow) [171]. Selectivity to the cis isomer could be tuned by varying the liquid and the gas bubble slug length in that case. The optimized conditions showed slightly lower ene selectivity (91.4\%) for this type of reactor. Similarly, commercial 5\% Pd@charcoal operating in a slurry-type mode resulted in high selectivity in the presence of $\mathrm{KOH}$ and $323 \mathrm{~K}$ (Table 2, entry 23) [172].

As an alternative to palladium, a $1 \mathrm{wt} \%$ platinum catalyst supported onto calcium carbonate was also reported, however, with no practical advantages over Pd in terms of partial hydrogenation (27\% ene selectivity at $78 \%$ conversion and $373 \mathrm{~K})$ [173].

\section{Methyl phenylpropiolate and 4-phenyl-3-butyn-2-one} The continuous hydrogenation of internal alkynes in presence of other functional groups other than alcohols was examined, for instance using the carbonyl derivatives methyl phenylpropiolate (14) and 4-phenyl-3-butyn-2-one (15). Both compounds were hydrogenated using the $\operatorname{Pd@Monobor~monolithic~catalyst~}$ under mild conditions with $>91 \%$ ene selectivity, and cis selectivity of $96 \%$ and $50 \%$, respectively, at conversions higher than 90\% (Table 2, entries 24, 25) [136]. Comparable selectivity results were obtained in batch using the Lindlar catalysts [174,175], Pd onto pumice [176] or onto nitrogen-doped carbon nanofibers [177], in the presence of $2.5-30 \%$ amine additives.

A variety of other single alkyne substrates have been hydrogenated under continuous-flow conditions using packed catalysts consisting of immobilized metal complexes. We refer the readers to the specific literature for these systems $[178,179]$.

\section{Substrate scope}

An explanation for efficiency differences observed in catalytic flow reactors in relation to the molecular structure and/or sub- 
stituent groups of alkynes substrates is not apparent due to a number of reasons.

For example, although a higher selectivity in partial hydrogenation was reported for 1-hexyne $(67 \%, 1)$ compared to 1-heptyne (ca. 90\%, 2) under analogous conditions (30\% conversion, room temperature, 1 bar $\mathrm{H}_{2}$, hydrocarbon solvent), hydrogenation experiments were carried out using different catalysts, namely 1\% Pd@ $\mathrm{Al}_{2} \mathrm{O}_{3}$ for $\mathbf{1}[121]$ and 2\% $\mathrm{Pd} @ \mathrm{Al}_{2} \mathrm{O}_{3}$ for $\mathbf{2}$ [126], and reactor setups. Therefore, any effect of the alkyl chain length is to be considered with care in this case. Studies were reported for the continuous hydrogenation of 1-hexyne and 1-decyne by 16\% $\mathrm{CeO}_{2} @ \mathrm{TiO}_{2}$ catalyst under the same experimental conditions, showing a positive effect of chain length on selectivity (ca. 4\% increase at full conversion) [119]. No justification for this evidence was proposed, however, a lower stability of the active site-adsorbed alkene intermediate with increasing steric hindrance may be hypothesized, which results in fewer interactions with hydrogen species, thus in enhanced the selectivity of the process [180].

On the other hand, a slightly negative effect of the alkyl substituent length on the selectivity of 2-methyl-3-butyn-2-ol (3) and 3-methyl-1-pentyn-3-ol (4) alcohols hydrogenation was demonstrated, for different Pd packed catalysts under the same conditions and substrate conversion [121]. Selectivity for $\mathbf{3}$ was equal or higher to that of bulkier 4, irrespective whether Pd(HHDMA)@C,Pd(HHDMA)@TiS, Lindlar or Pd@ $\mathrm{Al}_{2} \mathrm{O}_{3}$ catalyst was used (Figure 14).

Similarly, the hydrogenation of 2-methyl-3-butyn-2-ol (3) and 1,1-diphenyl-2-propyn-1-ol (6), bearing methyl and phenyl substituents, respectively, has been explored with a variety of catalytic flow reactors. While direct comparison in terms of substrate conversion is prevented by non-uniformity of reaction conditions, the dearth of a common trend emerges in terms of selectivity at the same level of conversion. An overall picture of experimental findings is summarized in Table 3. Selectivity for $\mathbf{6}$ is higher than that of $\mathbf{3}$ for Pd@TiNT and Lindlar packed catalysts, whereas the reverse is observed for monolithic $\mathrm{Pd} @$ MonoBor and packed $\mathrm{Ag} @ \mathrm{SiO}_{2}$. Given the large differences in the reactor systems, no rationale for these data can be hypothesized in the absence of theoretical or mechanistic studies.

Phenylacetylene (7), 1-bromo-4-ethynyl benzene (8) and 1-ethynyl-4-nitrobenzene (9) were hydrogenated using a Pd@C catalyst with trimodal pore-size distribution [152]. The chemoselectivity to the corresponding alkene product showed to follow the order $\mathbf{7}>>\mathbf{8}>\mathbf{9}$, under the same reaction conditions and comparable conversion. This result may be attributed to the

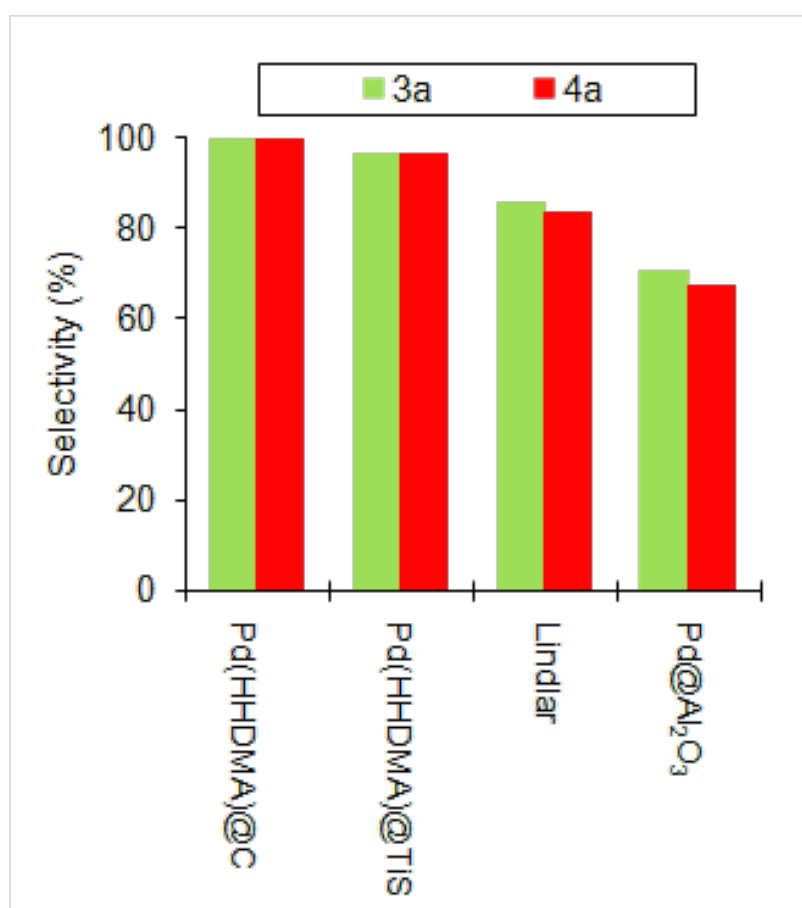

Figure 14: Selectivity of the continuous-flow partial hydrogenation reaction of $\mathbf{3}$ and $\mathbf{4}$ over packed-bed Pd catalysts at the same conversion level. Data from ref. [121].

Table 3: Relative selectivity in the continuous-flow partial hydrogenation reaction of $\mathbf{3}$ and $\mathbf{6}$ at comparable conversion level.

\begin{tabular}{|c|c|c|c|}
\hline \multirow[t]{2}{*}{ catalyst } & \multicolumn{2}{|c|}{ alkyne } & \multirow[t]{2}{*}{ ref. } \\
\hline & 3 & 6 & \\
\hline 0.67\% Pd@MonoBora & higher & & [136] \\
\hline 0.5\% Pd@TiNT & & higher & [137] \\
\hline $5 \% \mathrm{Pd}(\mathrm{Pb}) @ \mathrm{CaCO}_{3}{ }^{\mathrm{c}}$ & & higher & [123] \\
\hline $16 \% \mathrm{CeO}_{2} @ \mathrm{TiO}_{2}{ }^{\mathrm{d}}$ & \multicolumn{2}{|c|}{ equal } & [123] \\
\hline $1.3 \% \mathrm{Ag} @ \mathrm{SiO}_{2}{ }^{\mathrm{e}}$ & \multicolumn{2}{|l|}{ higher } & [123] \\
\hline $1 \% \mathrm{Au} @ \mathrm{TiO}_{2}{ }^{\mathrm{e}}$ & \multicolumn{2}{|c|}{ equal } & [123] \\
\hline
\end{tabular}

${ }^{a}$ ca. $90 \%$ conversion, $293 \mathrm{~K}$, ca. 1.5 bar $\mathrm{H}_{2} \cdot{ }^{\mathrm{b}} \mathrm{ca} .75 \%$ conversion, $293 \mathrm{~K}$, ca. 2.7 bar $\mathrm{H}_{2} .{ }^{\mathrm{c}} 30 \%$ conversion, $293 \mathrm{~K}, 1$ bar $\mathrm{H}_{2} .{ }^{\mathrm{d}} 30 \%$ conversion, $413 \mathrm{~K}, 40$ bar $\mathrm{H}_{2}$. ${ }^{\mathrm{e}} 30 \%$ conversion, $373 \mathrm{~K}, 10$ bar $\mathrm{H}_{2}$.

increasing stabilization of the intermediate alkene due to the electron-withdrawing properties of the alkyne substituents (nitro $>$ bromo $>>$ unsubstituted).

Data were reported for the partial hydrogenation of 3-hexyne (10) and the parent alcohol 3-hexyn-1-ol (11) by mean of Lindlar catalysts (Table 2, entries 2 and 13) [119,136]. At comparable substrate conversion, the selectivity was significantly lower for the latter. Based on DFT calculations, a similar effect was justified for the hydrogenation of alkynols in terms 
of strong adsorption of alcohols on the Pd surface, that increases the contact time with catalyst, thereby resulting in lower selectivity [121].

The continuous hydrogenation of 3-phenyl-2-propyn-1-ol (12), methyl phenylpropiolate (14) and 4-phenyl-3-butyn-2-one (15), bearing $-\mathrm{CH}_{2} \mathrm{OH},-\mathrm{CO}_{2} \mathrm{CH}_{3}$ and $-\mathrm{COCH}_{3}$ substituents at the 1-position of phenylacetylene moiety, respectively, was investigated using the Pd@MonoBor catalyst [136]. Although a conversion and productivity trend cannot be highlighted due to the lack of experimental data under the same reaction conditions (concentration, $\mathrm{H}_{2}$ :substrate molar ratio), the ene selectivity showed to decrease in the order $\mathbf{1 5}>\mathbf{1 4}>\mathbf{1 2}$ at comparable conversions (90-96\%), that can be related to the stabilization of the alkene product by the deactivating keto groups, despite a contribution of adsorption energy of alcohol group cannot be ruled out.

\section{Conclusion}

The selective, partial hydrogenation reaction of $\mathrm{C} \equiv \mathrm{C}$ bonds is a process of high relevance in the current manufacturing technology of a variety of intermediates for the fine-chemical industry. The conventional batch processes employing Pd catalysts are often problematic because of selectivity issues, need of toxic additives, high metal loadings and limited catalyst resistance. Ever increasing environmental and economic constraints have boosted the development of innovative catalytic materials and processes with improved performance and lower environmental impact.

Great advancements have been achieved in the recent years in the design of continuous-flow systems for alkynes partial hydrogenation, showing efficiency that often surpass that of the industrial protocols. Two main elements of comparison can be highlighted.

Batch versus flow setup. While experimental comparison can be easily carried out, continuous-flow reactors are practically advantageous with respect to the corresponding batch systems in the instance that the same catalyst produces at least the same amount of desired product per mole of metal and unit time, under similar reaction conditions. Most examples illustrated above show that this is indeed the case. Selectivities comparable to that of batch systems have been achieved using flow reactors, with the unquestionable advantage that no additives are usually required. Higher activity of continuous-flow versus stirred-tank batch reactors was attributed to faster molecular flow to and from the active sites, as a consequence of both the larger surface area of the catalyst in contact with the reagents (convective mass transfer), and a more efficient permeation of fluids through the material (diffusive mass transfer), which facilitates a reaction transition from a diffusion-controlled to kinetic-limited regime $[163,181]$. The non-accumulation of co-products adsorbed on the catalyst surface may also significantly contribute to the minimization of active site inhibition under the conditions of continuous flow [27].

Flow reactor design. Performance differences among different continuous-flow reactor designs are difficult to rationalize due to the number of additional variables related to the catalyst involved, which include:

- the role played by the supported metal, e.g., type, loading, MNP size, shape and location [182,183]),

- the role played by the support material, e.g., acid/base properties [184,185], morphology, grain size [186], porosity [187], strong metal-support interactions, swelling propensity [188]). In propyne hydrogenation, for instance, catalyst resistance was shown to decrease with increasing acidity of the support [189].

In order to establish a proper comparison, the experimental conditions should also be reproduced with care. In alkynes partial hydrogenation, the higher the conversion, the lower is the selectivity. Therefore, selectivity of different systems shall be compared at the same conversion level, or better, selectivity/ conversion diagrams shall be obtained by investigation of appropriate operating windows in relation to reagents flow rates, residence time, hydrogen/substrate ratio. Comparison between different systems requires a systematic study enucleating the contribution of each of the above factors, which is usually hampered by the lack or inhomogeneity of experimental data. In practice, to the best of our knowledge, no such analysis was carried out comparing the same catalyst under analogous flow reaction conditions in different reactor setups for liquid phase alkynes hydrogenation. Comparison between monolithic and packed (crushed material) arrangements was reported for $\mathrm{Pd} @ \mathrm{TiO}_{2}$ monolith catalyst and cyclohexene hydrogenation [163].

Despite no general conclusion can be drawn, structured monolithic reactors have usually shown superior performance with respect of packed-bed systems $[162,163]$. Due to their high permeability, monolithic materials allow for high substrate flow rates, weight hourly space velocities and low $\mathrm{H}_{2}$ back-pressures. As a consequence, the residence time of the intermediate alkene formed by hydrogenation is very short and it is continuously removed from the active sites with limited chance of further reduction. This results in an enhanced selectivity and productivity of semi-hydrogenation compound. When conventional (packed) mesoporous heterogeneous catalysts are used, the substrate undergoes a significant interaction with the metal sites 
inside the pores. The intermediate alkene is not swept away fast enough and it can react again before leaving the catalyst, thus resulting in a preferential formation of over-hydrogenation product at the same conversion level [190].

The activity of Pd-based catalysts is acknowledged to increase with decreasing particle size [191,192]. However, controversial statements can be found in the literature regarding the catalyst selectivity [193,194]. In the case of 2-methyl-3-butyn-2-ol (3) hydrogenation, the optimal catalyst in terms of desired partial hydrogenation productivity was established to be based on cubic PdNP of 3-5 nm length [195]. The combination of small metal particle size (high activity) and high flow rates (short contact time), as, e.g., in 1D materials or macroporous monoliths, seems, therefore, beneficial for continuous-flow partial hydrogenation of alkynes. In conclusion, the identification of the most effective and versatile catalytic system is difficult, since the choice is ruled by a variety factors to be evaluated, including selected performance indicators (product purity, productivity) and technical/economic parameters (cost and lifetime of the catalyst, reproducibility, reaction conditions, e.g., temperature, hydrogen pressure).

\section{References}

1. Pollak, P. Fine Chemicals: The Industry and the Business; Wiley-Interscience: Hoboken, 2007.

2. Chen, B.; Dingerdissen, U.; Krauter, J. G. E.; Lansink Rotgerink, H. G. J.; Möbus, K.; Ostgard, D. J.; Panster, P.; Riermeier, T. H.; Seebald, S.; Tacke, T.; Trauthwein, H. Appl. Catal., A 2005, 280, 17-46. doi:10.1016/j.apcata.2004.08.025

3. Nishimura, S. Handbook of Heterogeneous Catalytic Hydrogenation for Organic Synthesis; Wiley: New York, 2001; p 148.

4. Molnár, A.; Sárkány, A.; Varga, M. J. Mol. Catal. A 2001, 173, 185-221. doi:10.1016/S1381-1169(01)00150-9

5. Borodzínski, A.; Bond, G. C. Catal. Rev.: Sci. Eng. 2006, 48, 91-144. doi:10.1080/01614940500364909

6. King, A. O.; Larsen, R. D.; Negishi, E.-i. Palladium-Catalyzed Heterogeneous Hydrogenation. In Handbook of Organopalladium Chemistry for Organic Synthesis; Negishi, E., Ed.; Wiley: New York, 2002; pp 2719 ff. doi:10.1002/0471212466.ch124

7. Vilé, G.; Albani, D.; Almora-Barrios, N.; López, N.; Pérez-Ramírez, J. ChemCatChem 2016, 8, 21-33. doi:10.1002/cctc.201501269

8. Lindlar, H. Helv. Chim. Acta 1952, 35, 446-450. doi:10.1002/hlca.19520350205

9. Lindlar, H.; Dubuis, R. Org. Synth. 1966, 46, 89. doi:10.15227/orgsyn.046.0089

10. García-Mota, M.; Gómez-Díaz, J.; Novell-Leruth, G.; Vargas-Fuentes, C.; Bellarosa, L.; Bridier, B.; Pérez-Ramírez, J.; López, N. Theor. Chem. Acc. 2011, 128, 663-673. doi:10.1007/s00214-010-0800-0

11. McEwen, A. B.; Guttieri, M. J.; Maier, W. F.; Laine, R. M.; Shvo, Y. J. Org. Chem. 1983, 48, 4436-4438. doi:10.1021/jo00171a069

12. Jung, A.; Jess, A.; Schubert, T.; Schütz, W. Appl. Catal., A 2009, 362, 95-105. doi:10.1016/j.apcata.2009.04.026
13. Campos, K. R.; Cai, D.; Journet, M.; Kowal, J. J.; Larsen, R. D.; Reider, P. J. J. Org. Chem. 2001, 66, 3634-3635. doi:10.1021/jo015514a

14. Studt, F.; Abild-Pedersen, F.; Bligaard, T.; Sørensen, R. Z.; Christensen, C. H.; Nørskov, J. K. Science 2008, 320, 1320-1322. doi:10.1126/science.1156660

15. Armbrüster, M.; Kovnir, K.; Friedrich, M.; Teschner, D.; Wowsnick, G.; Hahne, M.; Gille, P.; Szentmiklósi, L.; Feuerbacher, M.; Heggen, M.; Girgsdies, F.; Rosenthal, D.; Schlögl, R.; Grin, Y. Nat. Mater. 2012, 11, 690-693. doi:10.1038/nmat3347

16. Stankiewicz, A. I.; Moulijn, J. A. Chem. Eng. Prog.; 2000; Vol. January, pp 22-34.

17. Wiles, C.; Watts, P. Green Chem. 2014, 16, 55-62. doi:10.1039/C3GC41797B

18. Ricciardi, R.; Huskens, J.; Verboom, W. ChemSusChem 2015, 8 , 2586-2605. doi:10.1002/cssc.201500514

19. Myers, R. M.; Fitzpatrick, D. E.; Turner, R. M.; Ley, S. V. Chem. - Eur. J. 2014, 20, 12348-12366. doi:10.1002/chem.201402801

20. Lucarelli, C.; Vaccari, A. Green Chem. 2011, 13, 1941-1949. doi:10.1039/c0gc00760a

21. Andrews, I.; Dunn, P.; Hayler, J.; Hinkley, B.; Hughes, D.; Kaptein, B.; Lorenz, K.; Mathew, S.; Rammeloo, T.; Wang, L.; Wells, A.; White, T. D. Org. Process Res. Dev. 2011, 15, 22-30. doi:10.1021/op1003105

22. Sheldon, R. A.; Arends, I. W. C. E.; Hanefeld, U. Green Chemistry and Catalysis; Wiley-VCH: Weinheim, 2007. doi:10.1002/9783527611003

23. Baxendale, I. R. J. Chem. Technol. Biotechnol. 2013, 88, 519-552. doi:10.1002/jctb.4012

24. Newman, S. G.; Jensen, K. F. Green Chem. 2013, 15, 1456-1472. doi:10.1039/c3gc40374b

25. Baumann, M.; Baxendale, I. R. Beilstein J. Org. Chem. 2015, 11, 1194-1219. doi:10.3762/bjoc.11.134

26. Jiménez-González, C.; Poechlauer, P.; Broxterman, Q. B.; Yang, B.-S.; am Ende, D.; Baird, J.; Bertsch, C.; Hannah, R. E.; Dell'Orco, P.; Noorman, H.; Yee, S.; Reintjens, R.; Wells, A.; Massonneau, V.; Manley, J. Org. Process Res. Dev. 2011, 15, 900-911. doi:10.1021/op100327d

27. Anderson, N. G. Org. Process Res. Dev. 2012, 16, 852-869. doi:10.1021/op200347k

28. Cossar, P. J.; Hizartzidis, L.; Simone, M. I.; McCluskey, A.; Gordon, C. P. Org. Biomol. Chem. 2015, 13, 7119-7130. doi:10.1039/C5OB01067E

29. Crespo-Quesada, M.; Cárdenas-Lizana, F.; Dessimoz, A.-L.; Kiwi-Minsker, L. ACS Catal. 2012, 2, 1773-1786. doi:10.1021/cs300284r

30. Bond, G. C. Metal-catalysed Reactions of Hydrocarbons; Springer: New York, 2005; p 292

31. Nikolaev, S. A.; Zanaveskin, L. N.; Smirnov, V. V.; Averyanov, V. A.; Zanaveskin, K. L. Russ. Chem. Rev. 2009, 78, 231-247. doi:10.1070/RC2009v078n03ABEH003893

32. Bos, A. N. R.; Westerterp, K. R. Chem. Eng. Process. 1993, 32, 1-7. doi:10.1016/0255-2701(93)87001-B

33. Natividad, R.; Cruz-Olivares, J.; Fishwick, R. P.; Wood, J.; Winterbottom, J. M. Fuel 2007, 86, 1304-1312. doi:10.1016/j.fuel.2006.12.005

34. Guo, X. C.; Madix, R. J. J. Catal. 1995, 155, 336-344. doi:10.1006/jcat.1995.1215 
35. Studt, F.; Abild-Pedersen, F.; Bligaard, T.; Sørensen, R. Z.; Christensen, C. H.; Nørskov, J. K. Angew. Chem., Int. Ed. 2008, 47, 9299-9302. doi:10.1002/anie.200802844

36. Tysoe, W. T.; Nyberg, G. L.; Lambert, R. M. J. Chem. Soc., Chem. Commun. 1983, 623-625. doi:10.1039/c39830000623

37. López, N.; Vargas-Fuentes, C. Chem. Commun. 2012, 48, 1379-1391. doi:10.1039/C1CC14922A

38. Bridier, B.; López, N.; Pérez-Ramírez, J. Dalton Trans. 2010, 39 , 8412-8419. doi:10.1039/c0dt00010h

39. García-Mota, M.; Bridier, B.; Pérez-Ramírez, J.; López, N. J. Catal. 2010, 273, 92-102. doi:10.1016/j.jcat.2010.04.018

40. Jakobsen, H. A. Chemical Reactor Modeling; Springer: Berlin, 2008.

41. Darvas,, F.; Hessel, V.; Dorman, G., Eds. Flow Chemistry; De Gruyter: Berlin, 2014; Vol. 1, Fundamentals.

42. Oger, C.; Balas, L.; Durand, T.; Galano, J.-M. Chem. Rev. 2013, 113, 1313-1350. doi:10.1021/cr3001753

43. Joannet, E.; Horny, C.; Kiwi-Minsker, L.; Renken, A. Chem. Eng. Sci. 2002, 57, 3453-3460. doi:10.1016/S0009-2509(02)00215-4

44. Lindlar, H.; Dubuis, R. Org. Synth. Coll.; 1973; Vol. 5, p 880.

45. Kiwi-Minsker, L.; Crespo-Quesada, M. Chimia 2011, 65, 699-703. doi:10.2533/chimia.2011.699

46. Guo, C.; Lu, X. Tetrahedron Lett. 1991, 32, 7549-7552. doi:10.1016/0040-4039(91)80531-A

47. Nicolaou, K. C.; Xu, J.-Y.; Kim, S.; Ohshima, T.; Hosokawa, S.; Pfefferkorn, J. J. Am. Chem. Soc. 1997, 119, 11353-11354. doi:10.1021/ja973000g

48. Hamprecht, D.; Josten, J.; Steglich, W. Tetrahedron 1996, 52, 10883-10902. doi:10.1016/0040-4020(96)00629-1

49. Knight, D. W.; Little, P. B. Tetrahedron Lett. 1998, 39, 5105-5108. doi:10.1016/S0040-4039(98)00937-X

50. Nowak, W.; Gerlach, H. Liebigs Ann. Chem. 1993, 153-159. doi:10.1002/jlac.199319930128

51. Organ, M. G.; Ghasemi, H. J. Org. Chem. 2004, 69, 695-700. doi:10.1021/jo035376k

52. Gueugnot, S.; Alami, M.; Linstrumelle, G.; Mambu, L.; Petit, Y.; Larchevêque, M. Tetrahedron 1996, 52, 6635-6646. doi:10.1016/0040-4020(96)00316-X

53. Dobson, N. A.; Eglinton, G.; Krishnamurthi, M.; Raphael, R. A.; Willis, R. G. Tetrahedron 1961, 16, 16-24. doi:10.1016/0040-4020(61)80050-1

54. Winterbottom, J. M.; Marwan, H.; Stitt, E. H.; Natividad, R. Catal. Today 2003, 79-80, 391-399. doi:10.1016/S0920-5861(03)00069-5

55. Middleton, R. L.; Lambert, R. M. Catal. Lett. 1999, 59, 15-20. doi:10.1023/A:1019027311804

56. Protasova, L. N.; Rebrov, E. V.; Choy, K. L.; Pung,, S. Y.; Engels, V.; Cabaj, M.; Wheatley, A. E. H.; Schouten, J. C. Catal. Sci. Technol. 2011, 1, 768-777. doi:10.1039/c1cy00074h

57. Hamilton, C. A.; Jackson, S. D.; Kelly, G. J.; Spence, R.; de Bruin, D. Appl. Catal., A 2002, 237, 201-209. doi:10.1016/S0926-860X(02)00332-0

58. Vilé, G.; Baudouin, D.; Remediakis, I. N.; Copéret, C.; López, N.; Pérez-Ramírez, J. ChemCatChem 2013, 5, 3750-3759. doi:10.1002/cctc.201300569

59. Nikolaev, S. A.; Smirnov, V. V. Catal. Today 2009, 147, S336-S341. doi:10.1016/j.cattod.2009.07.032

60. Tew, M. W.; Emerich, H.; van Bokhoven, J. A. J. Phys. Chem. C 2011, 115, 8457-8465. doi:10.1021/jp1103164
61. Baber, A. E.; Tierney, H. L.; Lawton, T. J.; Sykes, E. C. H. ChemCatChem 2011, 3, 607-614. doi:10.1002/cctc.201000309

62. Vilé, G.; Bridier, B.; Wichert, J.; Pérez-Ramírez, J. Angew. Chem., Int. Ed. 2012, 51, 8620-8623. doi:10.1002/anie.201203675

63. Kyriakou, G.; Boucher, M. B.; Jewell, A. D.; Lewis, E. A.; Lawton, T. J.; Baber, A. E.; Tierney, H. L.; Flytzani-Stephanopolous, M.; Sykes, E. C. H. Science 2012, 335, 1209-1212. doi:10.1126/science.1215864

64. Liguori, F.; Moreno-Marrodan, C.; Barbaro, P. Chin. J. Catal. 2015, 36, 1157-1169. doi:10.1016/S1872-2067(15)60865-8

65. Spee, M. P. R.; Boersma, J.; Meijer, M. D.; Slagt, M. Q.; van Koten, G.; Geus, J. W. J. Org. Chem. 2001, 66, 1647-1656. doi:10.1021/jo001246p

66. Nijhuis, T. A.; van Koten, G.; Kapteijn, F.; Moulijn, J. A. Catal. Today 2003, 79-80, 315-321. doi:10.1016/S0920-5861(03)00055-5

67. Shen, R.; Chen, T.; Zhao, Y.; Qiu, R.; Zhou, Y.; Yin, S.; Wang, X.; Goto, M.; Han, L.-B. J. Am. Chem. Soc. 2011, 133, 17037-17044. doi:10.1021/ja2069246

68. Derrien, M. L. Stud. Surf. Sci. Catal. 1986, 27, 613-666. doi:10.1016/S0167-2991(08)65364-1

69. Mori, A.; Miyakawa, Y.; Ohashi, E.; Haga, T.; Maegawa, T.; Sajiki, H. Org. Lett. 2006, 8, 3279-3281. doi:10.1021/ol061147j

70. Mitsudome, T.; Takahashi, Y.; Ichikawa, S.; Mizugaki, T.; Jitsukawa, K.; Kaneda, K. Angew. Chem., Int. Ed. 2013, 52, 1481-1485. doi:10.1002/anie.201207845

71. Takahashi, Y.; Hashimoto, N.; Hara, T.; Shimazu, S.; Mitsudome, T.; Mizugaki, T.; Jitsukawa, K.; Kaneda, K. Chem. Lett. 2011, 40, 405-407. doi:10.1246/cl.2011.405

72. McQuillin, F. J.; Ord, W. O.; Simpson, P. L. J. Chem. Soc. 1963, 5996-6003. doi:10.1039/jr9630005996

73. Semagina, N.; Kiwi-Minsker, L. Catal. Rev.: Sci. Eng. 2009, 51, 147-217. doi:10.1080/01614940802480379

74. Wegner, J.; Ceylan, S.; Kirschning, A. Adv. Synth. Catal. 2012, 354, 17-57. doi:10.1002/adsc.201100584

75. Webb, D.; Jamison, T. F. Chem. Sci. 2010, 1, 675-680. doi:10.1039/c0sc00381f

76. Levenspiel, O. Chemical Reaction Engineering, 3rd ed.; John Wiley \& Sons: New York, 1999

77. Goettmann, F.; Sanchez, C. J. Mater. Chem. 2007, 17, 24-30. doi:10.1039/B608748P

78. Pan, X.; Bao, X. Acc. Chem. Res. 2011, 44, 553-562. doi:10.1021/ar100160t

79. Wegner, J.; Ceylan, S.; Kirschning, A. Chem. Commun. 2011, 47, 4583-4592. doi:10.1039/c0cc05060a

80. Irfan, M.; Glasnov, T. N.; Kappe, C. O. ChemSusChem 2011, 4, 300-316. doi:10.1002/cssc.201000354

81. Kockmann, N.; Gottsponer, M.; Zimmermann, B.; Roberge, D. M. Chem. - Eur. J. 2008, 14, 7470-7477. doi:10.1002/chem.200800707

82. Kashid, M. N.; Kiwi-Minsker, L. Ind. Eng. Chem. Res. 2009, 48, 6465-6485. doi:10.1021/ie8017912

83. Harriot,, P. Chemical Reactors Design; Marcel Dekker: New York, 2002. doi:10.1201/9780203910238

84. Munirathinam, R.; Huskens, J.; Verboom, W. Adv. Synth. Catal. 2015, 357, 1093-1123. doi:10.1002/adsc.201401081

85. Jähnisch, K.; Hessel, V.; Löwe, H.; Baerns, M. Angew. Chem., Int. Ed. 2004, 43, 406-446. doi:10.1002/anie.200300577

86. Kobayashi, J.; Mori, Y.; Okamoto, K.; Akiyama, R.; Ueno, M.; Kitamori, T.; Kobayashi, S. Science 2004, 304, 1305-1308. doi:10.1126/science.1096956 
87. Hornung, C. H.; Hallmark, B.; Mackley, M. R.; Baxendale, I. R.; Ley, S. V. Adv. Synth. Catal. 2010, 352, 1736-1745. doi:10.1002/adsc.201000139

88. Bogdan, A. R.; Mason, B. P.; Sylvester, K. T.; McQuade, D. T. Angew. Chem. 2007, 119, 1728-1731. doi:10.1002/ange.200603854

89. Kolev, N. Packed bed columns: for absorption, desorption, rectification and direct heat transfer; Elsevier: Amsterdam, 2006.

90. Fogler, H. S. Essentials of Chemical Reaction Engineering; Prentice Hall: Upper Saddle River, 2011.

91. Corain, B.; Jerabek, K.; Centomo, P.; Canton, P. Angew. Chem., Int. Ed. 2004, 43, 959-962. doi:10.1002/anie.200352640

92. Bönnemann, H.; Richards, R. M. Eur. J. Inorg. Chem. 2001, 2455-2480.

doi:10.1002/1099-0682(200109)2001:10<2455::AID-EJIC2455>3.0.C $0 ; 2-Z$

93. Roucoux, A.; Schulz, J.; Patin, H. Chem. Rev. 2002, 102, 3757-3778. doi:10.1021/cr010350j

94. Lewera, A.; Timperman, L.; Roguska, A.; Alonso-Vante, N. J. Phys. Chem. C 2011, 115, 20153-20159. doi:10.1021/jp2068446

95. Kim, W.-J.; Moon, S. H. Catal. Today 2012, 185, 2-16. doi:10.1016/j.cattod.2011.09.037

96. European Agency for the Evaluation of Medicinal Products, Note for guidance on specification limits for residues of metal catalysts, EMEA/CHMP/SWP/4446/2000, February 2008.

97. Baumann, M.; Baxendale, I. R.; Ley, S. V. Mol. Diversity 2011, 15, 613-630. doi:10.1007/s11030-010-9282-1

98. Cybulski, A.; Moulijn, J. A. Structured Catalysts and Reactors; Marcel Dekker Ltd.: New York, 2005; p 19. doi:10.1201/9781420028003

99. Heck, R. M.; Gulati, S.; Farrauto, R. J. Chem. Eng. J. 2001, 82, 149-156. doi:10.1016/S1385-8947(00)00365-X

100.Tomašić, V.; Jović, F. Appl. Catal., A 2006, 311, 112-121. doi:10.1016/j.apcata.2006.06.013

101.Natividad, R.; Kulkarni, R.; Nuithitikul, K.; Raymahasay, S.; Wood, J.; Winterbottom, J. M. Chem. Eng. Sci. 2004, 59, 5431-5438. doi:10.1016/j.ces.2004.09.011

102.Alemán, J.; Chadwick, A. V.; He, J.; Hess, M.; Horie, K.; Jones, R. G.; Kratochvil, P.; Meisel, I.; Mita, I.; Moad, G.; Penczek, S.; Stepto, R. F. T. Pure Appl. Chem. 2007, 79, 1801-1829. doi:10.1351/pac200779101801

103. Nakanishi, K.; Tanaka, N. Acc. Chem. Res. 2007, 40, 863-873. doi:10.1021/ar600034p

104.Sachse, A.; Galarneau, A.; Coq, B.; Fajula, F. New J. Chem. 2011, 35, 259-264. doi:10.1039/c0nj00965b

105.Stankiewicz, A. Chem. Eng. Sci. 2001, 56, 359-364. doi:10.1016/S0009-2509(00)00236-0

106.Sachse, A.; Galarneau, A.; Fajula, F.; Di Renzo, F.; Creux, P.; Coq, B. Microporous Mesoporous Mater. 2011, 140, 58-68. doi:10.1016/j.micromeso.2010.10.044

107. Nakanishi, K. In Hierarchically Structured Porous Materials; Su, B.; Sanchez, C.; Yang, X., Eds.; Chapter 8; Wiley-VCH: Weinheim, 2012.

108. Feinle, A.; Elsaesser, M. S.; Hüsing, N. Chem. Soc. Rev. 2016, 45 , 3377-3399. doi:10.1039/C5CS00710K

109.Galarneau, A.; Sachse, A.; Said, B.; Pelisson, C.-H.; Boscaro, P.; Brun, N.; Courtheoux, L.; Olivi-Tran, N.; Coasne, B.; Fajula, F. C. R. Chim. 2016, 19, 231-247. doi:10.1016/j.crci.2015.05.017

110.Grano, A. J.; Sayler, F. M.; Smått, J. H.; Bakker, M. G. J. Porous Mater. 2014, 21, 1113-1122. doi:10.1007/s10934-014-9861-0
111. Nakanishi, K. J. Porous Mater. 1997, 4, 67-112. doi:10.1023/A:1009627216939

112.Galarneau, A.; Abid, Z.; Said, B.; Didi, Y.; Szymanska, K.; Jarzębski, A.; Tancret, F.; Hamaizi,, H.; Bengueddach, A.; Di Renzo, F.; Fajula, F. Inorganics 2016, 4, 9-34. doi:10.3390/inorganics4020009

113. Whitaker, S. Ind. Eng. Chem. 1969, 61, 14-28. doi:10.1021/ie50720a004

114. Nauman, E. In Handbook of Industrial Mixing: Science and Practice; Paul, E. L.; Atiemo-Obeng, V. A.; Kresta, S. M., Eds.; Chapter 1; Wiley: New York, 2003.

115.Pletcher, D.; Walsh, F. Industrial Electrochemistry; Springer: London, 1990; p 83.

116. Redshaw, C.; Tang, Y. Chem. Soc. Rev. 2012, 41, 4484-4510. doi:10.1039/c2cs35028a

117. Krentsel, B. A.; Kissin, Y. V.; Kleiner, V. J.; Stotskaya, L. L. Polymers and Copolymers of Higher Alpha-Olefins; Carl Hanser Verlag: Munich, 1997.

118. Van Puyvelde, P.; Velankar, S.; Moldenaers, P. Curr. Opin. Colloid Interface Sci. 2001, 6, 457-463. doi:10.1016/S1359-0294(01)00113-3

119. Vilé, G.; Wrabetz, S.; Floryan, L.; Schuster, M. E.; Girgsdies, F.; Teschner, D.; Pérez-Ramírez, J. ChemCatChem 2014, 6, 1928-1934. doi:10.1002/cctc. 201402124

120.Kirby, F.; Moreno-Marrodan, C.; Baán, Z.; Bleeker, B. F.; Barbaro, P.; Berben, P. H.; Witte, P. T. ChemCatChem 2014, 6, 2904-2909. doi:10.1002/cctc. 201402310

121.Vilé, G.; Almora-Barrios, N.; Mitchell, S.; López, N.; Pérez-Ramírez, J. Chem. - Eur. J. 2014, 20, 5926-5937. doi:10.1002/chem.201304795

122.Vilé, G.; Albani, D.; Nachtegaal, M.; Chen, Z.; Donsova, D.; Antonietti, M.; López, N.; Pérez-Ramírez, J. Angew. Chem., Int. Ed. 2015, 54, 11265-11269. doi:10.1002/anie.201505073

123. Vilé, G.; Pérez-Ramírez, J. Nanoscale 2014, 6, 13476-13482. doi:10.1039/C4NR02777A

124. Chen, Z.; Pronkin, S.; Fellinger, T.-P.; Kailasam, K.; Vilé, G.; Albani, D.; Krumeich, F.; Leary, R.; Barnard, J.; Thomas, J. M.; Perez-Ramírez, J.; Antonietti, M.; Dontsova, D. ACS Nano 2016, 10 , 3166-3175. doi:10.1021/acsnano.5b04210

125. Bridger, R. F. Alpha-olefin polymers as lubricant viscosity properties improvers (Mobil Oil Corporation). U.S. Patent US4613712 (A), Sept 23, 1986.

126. Al-Herz, M.; Simmons, M. J. H.; Wood, J. Ind. Eng. Chem. Res. 2012, 51, 8815-8825. doi:10.1021/ie201955m

127.3-Buten-2-ol, 2-methyl, CAS No.: 115-18-4, UNEP Publications, International Programme on Chemical Safety (IPCS).

128. Baglai, A. K.; Gurarii, L. L.; Kuleshov, G. G. J. Chem. Eng. Data 1988, 33, 512-518. doi:10.1021/je00054a035

129.Semagina, N.; Renken, A.; Laub, D.; Kiwi-Minsker, L. J. Catal. 2007, 246, 308-314. doi:10.1016/j.jcat.2006.12.011

130. Crespo-Quesada, M.; Grasemann, M.; Semagina, N.; Renken, A.; Kiwi-Minsker, L. Catal. Today 2009, 147, 247-254. doi:10.1016/j.cattod.2008.09.035

131.Rebrov, E. V.; Klinger, E. A.; Berenguer-Murcia, A.; Sulman, E. M.; Schouten, J. C. Org. Process Res. Dev. 2009, 13, 991-998. doi:10.1021/op900085b

132. Okhlopkova, L. B.; Kerzhentsev, M. A.; Ismagilov, Z. R. Kinet. Catal. 2016, 57, 497-503. doi:10.1134/S0023158416040091

133.Liguori, F.; Coiai, S.; Passaglia, E.; Barbaro, P. Macromolecules 2013, 46, 5423-5433. doi:10.1021/ma401120v 
134.Illner, P.; Puchta, R.; Heinemann, F. W.; van Eldik, R. Dalton Trans. 2009, 2795-2801. doi:10.1039/b820940e

135. Nieto, S.; Pérez, J.; Riera, L.; Riera, V.; Miguel, D. Chem. Commun. 2009, 3279-3281. doi:10.1039/b823460d

136. Liguori, F.; Barbaro, P. J. Catal. 2014, 311, 212-220. doi:10.1016/j.jcat.2013.11.027

137. Linares, N.; Moreno-Marrodan, C.; Barbaro, P. ChemCatChem 2016, 8, 1001-1011. doi:10.1002/cctc.201501126

138. Burwell, R. L., Jr. Pure Appl. Chem. 1976, 46, 71-90. doi:10.1351/pac197646010071 IUPAC, Manual of Symbols and Terminology for Physicochemical Quantities and Units - Appendix II.

139. Semagina, N.; Grasemann, M.; Xanthopoulos, N.; Renken, A.; Kiwi-Minsker, L. J. Catal. 2007, 251, 213-222. doi:10.1016/j.jcat.2007.06.028

140.Centi, G.; Perathoner, S. CATTECH 2003, 7, 78-89. doi:10.1023/A:1023849024050

141.Grasemann, M.; Renken, A.; Kashid, M.; Kiwi-Minsker, L. Chem. Eng. Sci. 2010, 65, 364-371. doi:10.1016/j.ces.2009.06.063

142.Liguori, F.; Barbaro, P.; Sawa, H. Appl. Catal., A 2014, 488, 58-65. doi:10.1016/j.apcata.2014.09.029

143.Bakker, J. J. W.; Zieverink, M. M. P.; Reintjens, R. W. E. G.; Kapteijn, F.; Moulijn, J. A.; Kreutzer, M. T. ChemCatChem 2011, 3, 1155-1157. doi:10.1002/cctc.201100044

144.Carter, C. F.; Lange, H.; Sakai, D.; Baxendale, I. R.; Ley, S. V. Chem. - Eur. J. 2011, 17, 3398-3405. doi:10.1002/chem.201003148

145.Besson, M.; Gallezot, P. Catal. Today 2003, 81, 547-559. doi:10.1016/S0920-5861(03)00153-6

146. Nishio, R.; Sugiura, M.; Kobayashi, S. Org. Biomol. Chem. 2006, 4, 992-995. doi:10.1039/b517181d

147. Mastalir, A.; Király, Z.; Berger, F. Appl. Catal., A 2004, 269, 161-168. doi:10.1016/j.apcata.2004.04.012

148.Starodubtseva, E. V.; Vinogradov, M. G.; Turova, O. V.; Bumagin, N. A.; Rakov, E. G.; Sokolov, V. I. Catal. Commun. 2009, 10, 1441-1442. doi:10.1016/j.catcom.2009.03.012

149.Tschan, R.; Wandeler, R.; Schneider, M. S.; Schubert, M. M.; Baiker, A. J. Catal. 2001, 204, 219-229. doi:10.1006/jcat.2001.3364

150.Rebrov, E.V.; Berenguer-Murcia, A.; Skelton, H. E.; Johnson, B. F. G.; Schouten, J.C. 10th International Conference on Microreaction Technology, New Orleans, Louisiana, April 2008.

151.Li, S.-S.; Tao, L.; Wang, F.-Z.-R.; Liu, Y.-M.; Cao, Y. Adv. Synth. Catal. 2016, 358, 1410-1416. doi:10.1002/adsc.201501183

152.Fan, X.; Sans, V.; Sharma, S. K.; Plucinski, P. K.; Zaikovskii, V. A.; Wilson, K.; Tennison, S. R.; Kozynchenko, A.; Lapkin, A. A. Catal. Sci. Technol. 2016, 6, 2387-2395. doi:10.1039/C5CY01401H

153.Warr, J.; Fraser, S.; Gouault, O. Sensitive skin perfumes (Takasago Perfumery Co., Ltd.). Eur. Pat. Appl. EP 1964542, Sept 3, 2008.

154.Choi, J. Y.; Jeon, B. B.; Seo, H. J. Perfum composition for expressing the fragrance of green tea flower (Amorepacific Corp.). WO patent WO 2007055493, May 18, 2007.

155.Bönnemann, H.; Brijoux, W.; Siepen, K.; Hormes, J.; Franke, R.; Pollmann, J.; Rothe, J. Appl. Organomet. Chem. 1997, 11, 783-796. doi:10.1002/(SICI)1099-0739(199710/11)11:10/11<783::AID-AOC630 $>3.0 . \mathrm{CO} ; 2-\#$

156.Bönnemann, H.; Brijoux, W.; Schulze Tilling, A.; Siepen, K. Top. Catal. 1997, 4, 217-227. doi:10.1023/A:1019152625358

157.European Agency for the Evaluation of Medicinal Products, Note for Guidance on Specification Limits for Residues of Metal Catalysts, CPMP/SWP/QWP/ 4446/00, June 2002.
158. Roelofs, J. C. A. A.; Berben, P. H. Chem. Commun. 2004, 970-971. doi:10.1039/b400737a

159. Witte, P. T. Process for the preparation of an aqueous colloidal precious metal suspension (BASF Catalysts LLC). WO patent WO 2009096783, Aug 6, 2009.

160.Witte, P. T.; Boland, S.; Kirby, F.; van Maanen, R.; Bleeker, B. F.; de Winter, D. A. M.; Post, J. A.; Geus, J. W.; Berben, P. H. ChemCatChem 2013, 5, 582-587. doi:10.1002/cctc.201200460

161. Moreno-Marrodan, C.; Barbaro, P.; Catalano, M.; Taurino, A. Dalton Trans. 2012, 41, 12666-12669. doi:10.1039/c2dt31626a

162.Sachse, A.; Linares, N.; Barbaro, P.; Fajula, F.; Galarneau, A. Dalton Trans. 2013, 42, 1378-1384. doi:10.1039/C2DT31690K

163.Linares, N.; Hartmann, S.; Galarneau, A.; Barbaro, P. ACS Catal. 2012, 2, 2194-2198. doi:10.1021/cs3005902

164. Thomas, J.; Kuruvilla, K. M. In Handbook of Herbs and Spices, 2nd ed.; Peter, K. V., Ed.; Woodhead Publ.: Cambridge, 2012; Vol. 1, pp 182-196. doi:10.1533/9780857095671.182

165. Mizugaki, T.; Murata, M.; Fukubayashi, S.; Mitsudome, T.; Jitsukawa, K.; Kaneda, K. Chem. Commun. 2008, 241-243. doi:10.1039/B710860E

166. Rode, C. V. J. Jpn. Pet. Inst. 2008, 51, 119-133. doi:10.1627/jpi.51.119

167. Hoffmann, H.; Boettger, G.; Bör, K.; Wache, H.; Kräfje, H.; Cörning, W. Catalyst for partial hydrogenation (BASF AG). U.S. Patent US 4001344 (A), Jan 4, 1977.

168. Isaeva, V. I.; Tkachenko, O. P.; Afonina, E. V.; Kozlova, L. M.; Kapustin, G. I.; Grünert, W.; Solov'eva, S. E.; Antipin, I. S.; Kustov, L. M. Microporous Mesoporous Mater. 2013, 166, 167-175. doi:10.1016/j.micromeso.2012.04.030

169.Semagina, N.; Joannet, E.; Parra, S.; Sulman, E.; Renken, A.; Kiwi-Minsker, L. Appl. Catal., A 2005, 280, 141-147. doi:10.1016/j.apcata.2004.10.049

170.Fishwick, R. P.; Natividad, R.; Kulkarni, R.; McGuire, P. A.; Wood, J.; Winterbottom, J. M.; Stitt, E. H. Catal. Today 2007, 128, 108-114. doi:10.1016/j.cattod.2007.06.030

171.Tsoligkas, A. N.; Simmons, M. J. H.; Wood, J.; Frost, C. G. Catal. Today 2007, 128, 36-46. doi:10.1016/j.cattod.2007.07.001

172. Winterbottom, J. M.; Marwan, H.; Viladevall, J.; Sharma, S.; Raymahasay, S. Stud. Surf. Sci. Catal. 1997, 108, 59-66. doi:10.1016/S0167-2991(97)80888-9

173.Rode, C. V.; Tayade, P. R.; Nadgeri, J. M.; Jaganathan, R.; Chaudhari, R. V. Org. Process Res. Dev. 2006, 10, 278-284. doi:10.1021/op050216r

174. Belger, C.; Neisius, N. M.; Plietker, B. Chem. - Eur. J. 2010, 16 , 12214-12220. doi:10.1002/chem.201001143

175. Boldrini, G. P.; Bortolotti, M.; Mancini, F.; Tagliavini, E.; Trombini, C.; Umani-Ronchi, A. J. Org. Chem. 1991, 56, 5820-5826. doi:10.1021/jo00020a025

176. Gruttadauria, M.; Liotta, L. F.; Noto, R.; Deganello, G. Tetrahedron Lett. 2001, 42, 2015-2017. doi:10.1016/S0040-4039(01)00065-X

177.Lee, Y.; Motoyama, Y.; Tsuji, K.; Yoon, S.-H.; Mochida, I.; Nagashima, H. ChemCatChem 2012, 4, 778-781. doi:10.1002/cctc.201200058

178. Horváth, H. H.; Papp, G.; Csajági, C.; Joó, F. Catal. Commun. 2007, 8, 442-446. doi:10.1016/j.catcom.2006.07.016

179. Neumann, K. T.; Klimczyk, S.; Burhardt, M. N.; Bang-Andersen, B.; Skrydstrup, T.; Lindhardt, A. T. ACS Catal. 2016, 6, 4710-4714. doi:10.1021/acscatal.6b01045 
180.Teschner, D.; Borsodi, J.; Wootsch, A.; Révay, Z.; Hävecker, M.; Knop-Gericke, A.; Jackson, S. D.; Schlögl, R. Science 2008, 320, 86-89. doi:10.1126/science. 1155200

181.El Kadib, A.; Chimenton, R.; Sachse, A.; Fajula, F.; Galarneau, A.; Coq, B. Angew. Chem., Int. Ed. 2009, 48, 4969-4972. doi:10.1002/anie.200805580

182.Semagina, N.; Kiwi-Minsker, L. Catal. Lett. 2009, 127, 334-338. doi:10.1007/s10562-008-9684-1

183. Telkar, M. M.; Rode, C. V.; Chaudhari, R. V.; Joshi, S. S.; Nalawade, A. M. Appl. Catal., A 2004, 273, 11-19. doi:10.1016/j.apcata.2004.05.056

184.Berguerand, C.; Yuranov, I.; Cárdenas-Lizana, F.; Yuranova, T.; Kiwi-Minsker, L. J. Phys. Chem. C 2014, 118, 12250-12259. doi:10.1021/jp501326c

185.Seki, T.; Grundwaldt, J.-D.; van Vegten, N.; Baiker, A. Adv. Synth. Catal. 2008, 350, 691-705. doi:10.1002/adsc.200700532

186.Perego, C.; Peratello, S. Catal. Today 1999, 52, 133-145. doi:10.1016/S0920-5861(99)00071-1

187. Taguchi, A.; Schüth,, F. Microporous Mesoporous Mater. 2005, 77, 1-45. doi:10.1016/j.micromeso.2004.06.030

188. Knapik, A.; Drelinkiewicz, A.; Waksmundzka-Góra, A.; Bukowska, A.; Bukowski, W.; Noworól, J. Catal. Lett. 2008, 122, 155-166. doi:10.1007/s10562-007-9362-8

189. Wehrli, J. T.; Thomas, D. J.; Wainwright, M. S.; Trimm, D. L.; Cant, N. W. Appl. Catal. 1991, 70, 253-262. doi:10.1016/S0166-9834(00)84168-8

190.Louis, B.; Laugel, G.; Pale, P.; Maciel Pereira, M. ChemCatChem 2011, 3, 1263-1272. doi:10.1002/cctc. 201100110

191. Ruta, M.; Semagina, N.; Kiwi-Minsker, L. J. Phys. Chem. C 2008, 112, 13635-13641. doi:10.1021/jp803800w

192.Gross, E.; Liu, J. H.-C.; Toste, F. D.; Somorjai, G. A. Nat. Chem. 2012, 4, 947-952. doi:10.1038/nchem.1465

193. Borodziński, A.; Bond, G. C. Catal. Rev.: Sci. Eng. 2008, 50, 379-469. doi:10.1080/01614940802142102

194. Tew, M. W.; Miller, J. T.; van Bokhoven, J. A. J. Phys. Chem. C 2009 , 113, 15140-15147. doi:10.1021/jp902542f

195. Crespo-Quesada, M.; Yarulin, A.; Jin, M.; Xia, Y.; Kiwi-Minsker, L. J. Am. Chem. Soc. 2011, 133, 12787-12794. doi:10.1021/ja204557m

\section{License and Terms}

This is an Open Access article under the terms of the Creative Commons Attribution License (http://creativecommons.org/licenses/by/4.0), which permits unrestricted use, distribution, and reproduction in any medium, provided the original work is properly cited.

The license is subject to the Beilstein Journal of Organic Chemistry terms and conditions: (http://www.beilstein-journals.org/bjoc)

The definitive version of this article is the electronic one which can be found at: doi:10.3762/bjoc. 13.73 